Historic, Archive Document

Do not assume content reflects current scientific knowledge, policies, or practices. 



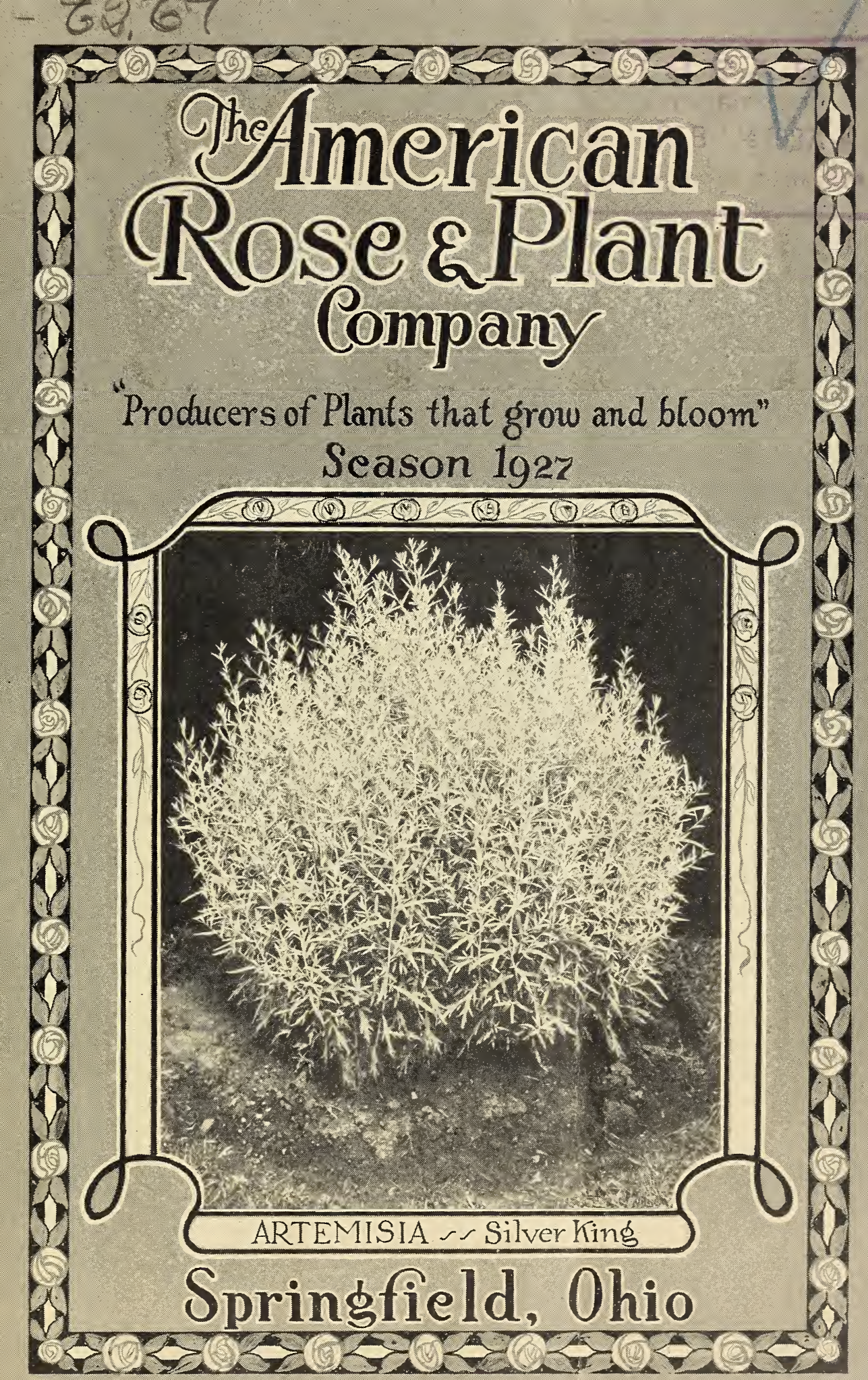




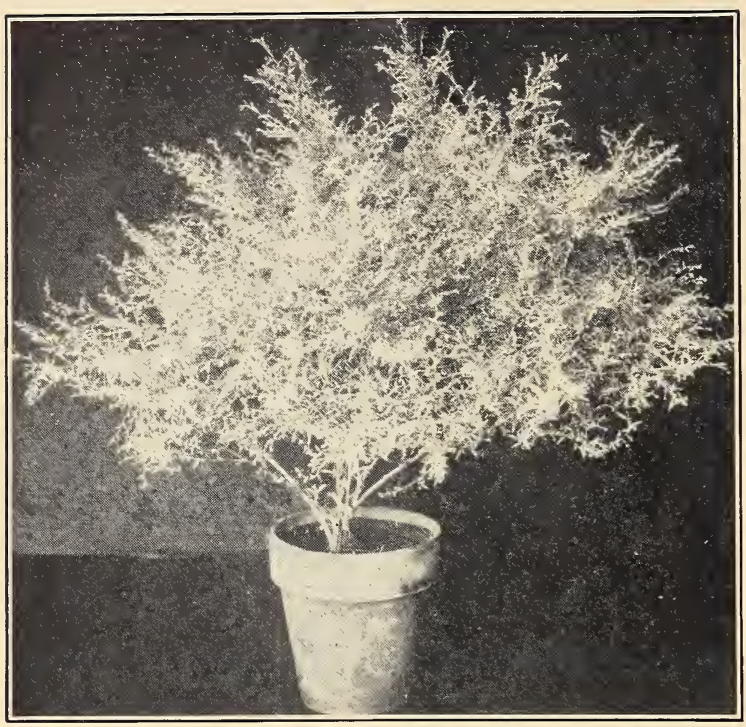

ARTEMISIA Sos Silver King

$A$ one year field plant lifted and potted
ARTEMISIA

Silver King

A Plant of Rare Beauty for Landscape or Cut Flowers

7. HIS Artemisia is one of ff such rare beauty and so valuable for various purposes that our description will hardly do it full justice.

For landscape effect from early summer until late winter, it is the most outstanding plant we have ever seen. lts bright silver-colored stems and foliage blend harmoniously with other foliage or blooming plants and its rich striking beauty in form and color is first to attract attention regardless of its surroundings.

For beautiful airy foliage to combine with cut flowers, it has no equal, as it does not wilt or shatter off and can be carried dry indefinitely without losing its color. When used with sparkling pink flowers, such as Radiance Roses, the effect is both indescribable and irresistible. The foliage matures early in the summer and quickly hardens to a state when it can be cut and used without moisture.

The illustration on the front cover of this catalog was made from an actual photograph taken July 2, 1926, of a plant in the open ground which has lived through two of our most severe winters without mulch or any protection, proving its absolute hardiness. lt thrives in ordinary soil, growing to a height of about three feet in almost perfect symmetrical form. The stems are well branched and thickly covered with bright silvercolored foliage which first appears in the form of small narrow leaves, but these quickly divide into a delicate lacy shape with the appearance of small flower buds all over the branches. Artemisia Silver King is not a variety of our own origination, but one which evidently has been lost in propagation, as we have been unable to find it among the plantings of any growers in the United States; or to locate a grower who has ever seen the same type or color of foliage as produced by this Artemisia.

Our original stock consisted of three small divisions which were secured six years ago from a very old lady who stated the plant had been in the family garden as far back as she could remember, and that to the best of her recollection, it was brought to the United States from Europe by her grandmother.

As Artemisia belongs to the perennial class, producing its entire new growth from the roots each year, we will fill all early orders with fine field grown roots in a dormant condition and orders received in the latter part of the Spring will be filled with plants which have been potted and foliaged out.

Extra Large Field Plants - - - $\$ 1.00$ each Medium Field Plants - . . . .50 each

\section{Special Introductory Offer}

We are anxious that all of our plant loving friends have this beautiful Artemisia Silver King in their garden so if you will send us an order amounting to $\$ 1.00$ or more, with the names and addresses of five of your friends interested in growing plants, we will send a fine pot plant to you FREE. 

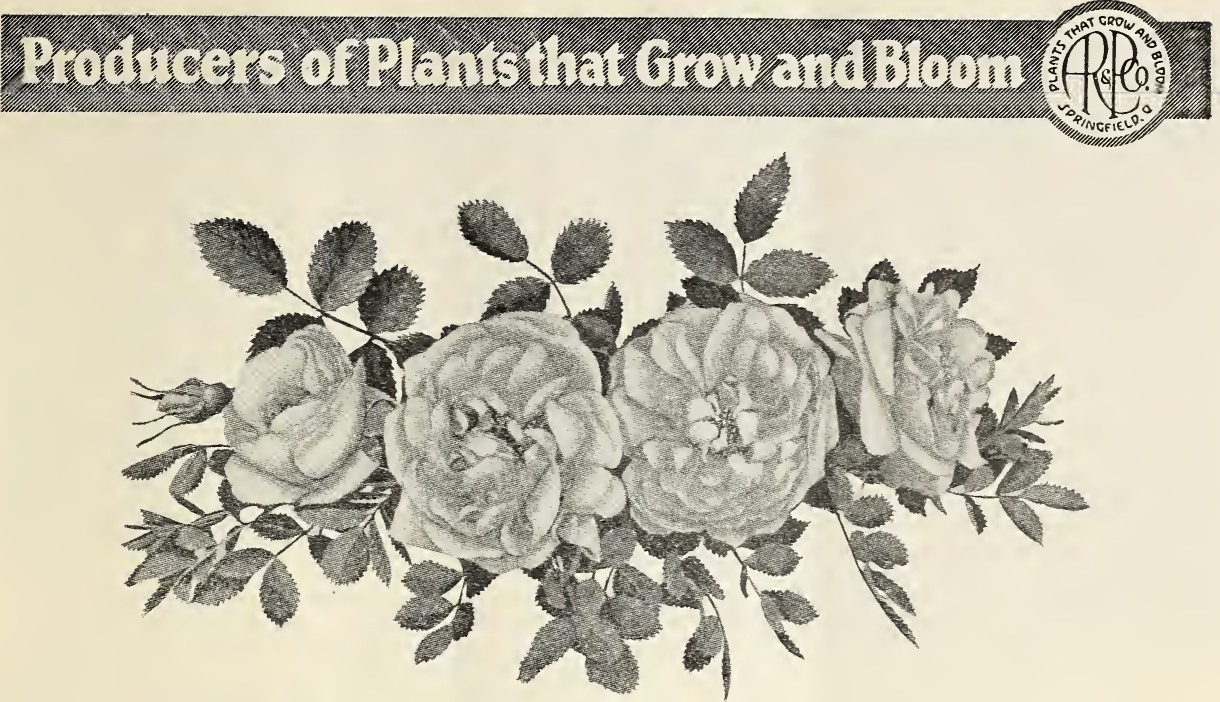

To Our Flower-Loving Friends:

$T \mathrm{HE}$ appreciation and love for trees, shrubs and flowers, as a part of one's own individual home has become a universal and dominant factor within the last few years.

Aside from the pleasure and beauty that well-grown and well-arranged plantings afford to the home, there is a decided advantage in a commercial way and this is worthy of

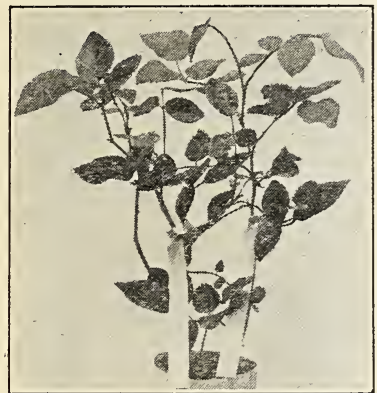

This Shows a Pot Grown One Year Rose Bush-Wrapped for Shipping

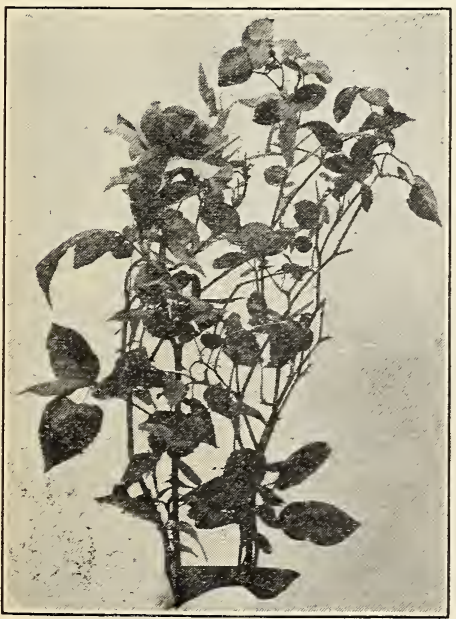

A Two Year Rose Bush Pot Grown Plant important consideration. In fact, a home buyer now considers flowers and shrubs a necessity. They give a look of prosperity and permanency that can be obtained in no other way.

Entrancing little gardens may be developed with the beautiful roses, flowering shrubs, vines, hedge plants and a generous intermingling of the gay, hardy perennials that we offer you in this book.

An experience covering many years has placed us in a position to supply stock, properly grown and dependable, every effort having been made to produce thrifty, robust plants, brimful of vitality, ready to grow and bloom as soon as planted in your garden. We believe that we can give you the best value for your money; based on the Quality, Price, Responsibility and Service that is assured with every order sent to us.

Our first consideration is the success of our patrons in their planting operations and we desire, above everything else, to maintain a high standard in the quality of our stock. Prices quoted in this catalog are as low as is consistent with quality and dependability.

The orders with which you have favored us in the past have been greatly appreciated and we trust that we may continue to enjoy your confidence.

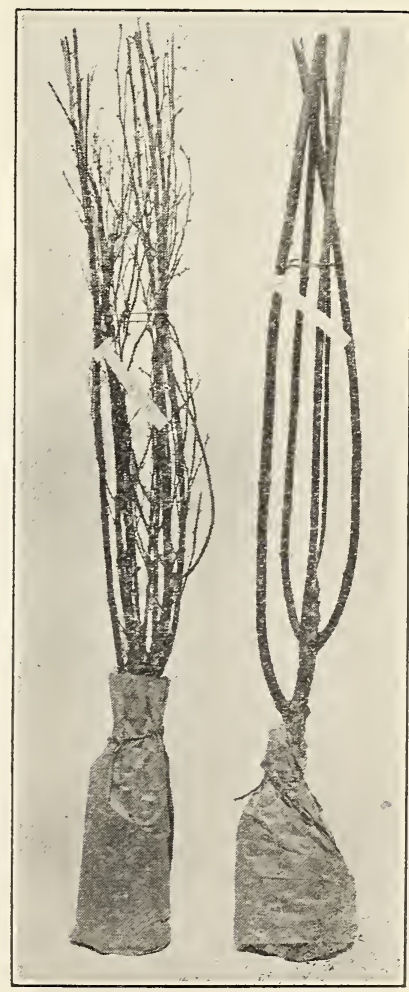

Dormant Field Grown Shrub Showing How They Will Come 


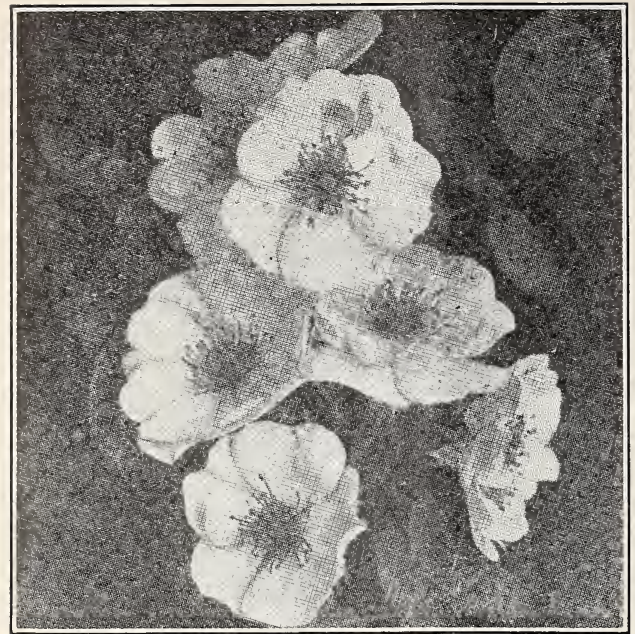

Hugonis-"The Golden Rose of China" Illustrated on Back Cover Page

\section{Hugonis}

\section{"The Golden Rose of China"}

\section{Blooms Three Weeks Earlier Than Most Roses}

A UNIQUE species as it is fine for shrub planting, either to mass or as single specimens. It grows gracefully and rapidly, producing numerous arching and drooping sprays which make a most symmetrical bush about six feet in height and the same in diameter when fully matured. Every branch of the previous year's growth is lined on both sides to the very tip with closely set, wide-open flowers of the most gorgeous golden-yellow, from two to three weeks before other roses are blooming. The delicate graceful sprays are fine for indoor decoration as the glowing yellow crepelike blooms harmonize with any color scheme. They come in huge masses in late April and May, and after blooming, the pale-green foliage on its curious redbrown twigs, turns to soft purple. All new growth springs from the roots and is beautiful reddish maroon; it provides the new canes for the next season's bloom.

Hugonis long remains an object of beauty, as it retains its finely veined and delicately cut miniature leaves until the ground is frozen.

It is entirely hardy, withstanding temperatures fa $r$ below zero, having been thorsughly tested in all northern localities.
Manayunk Sta, Pa., April 26, 1926 Just a line to tell you I have just received the Rose Bushes and very much pleased with them. I shall send for more Rose Bushes and Perennials next Spring after we move to our new home which will be in October or November-Miss C. Kaufman.

\section{The Two Most Popular American Roses}

\section{Red and Pink Radiance}

YOU can have roses like these in your own garden, as both Pink and Red Radiance will produce an abundance of large, fragrant, perfectly formed flowers from early Spring until late Fall. They represent perfection, in robust hardy growth, deep green foliage, which is disease and insect proof, free blooming qualities,

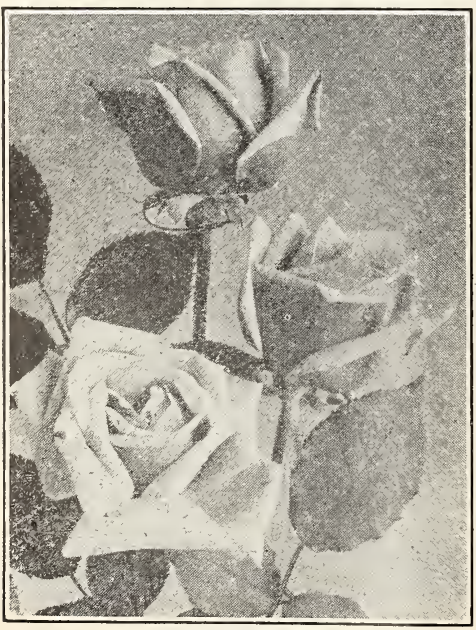

Pink Radiance flowers of wonderful size and substance with delicious fragrance and lastly, the amazing sparkling lovely colors, so brilliant and vivid as to well deserve a Radiant title.

For cut flowers to be used indoors, they have no equal.

The Pink Radiance is a deep uniform lively rose pink, with brilliant carmine and salmon tints.

The Red Radiance is a dazzling rich red, warm and bright, of a lustrous silky texture. Both varieties retain their deep pure color until the flowers are gone.

We offer you large Two Year Old Field Grown Plants properly pruned, ready to set out at $\$ 1.00$ each; Two for $\$ 1.50$; Five for $\$ 3.00$.

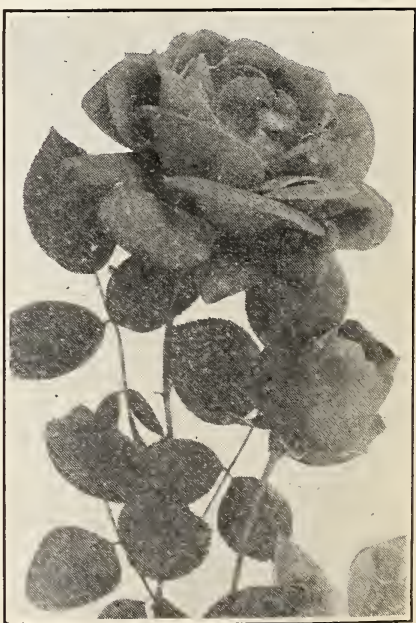

Red Radiance 


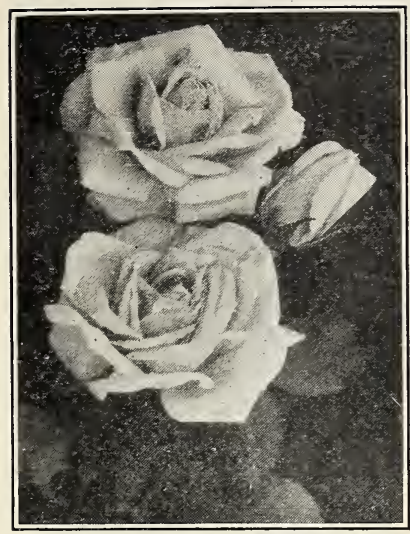

Souv. de Georges Pernet

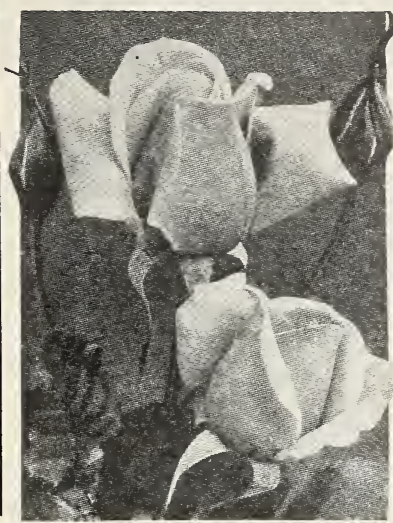

Rev. Page Roberts

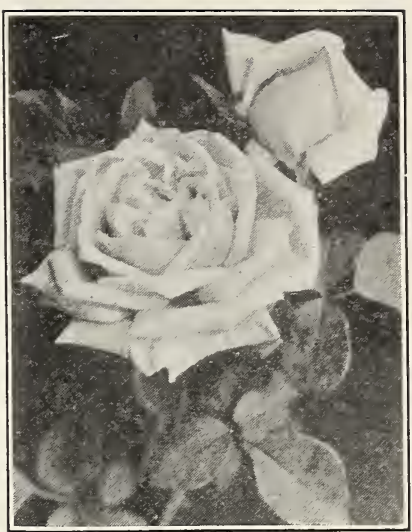

Independence Day

\section{Distinct New Everblooming Roses}

HERE are the most beautiful productions in new roses, carefully selected as those nearest to perfection. Nature has bestowed her charms upon them with a lavish hand and you may enjoy a season of perpetual bloom if you plant them in your garden.

INDEPENDENCE DAY-Flaming yellow buds, heavily shaded with copper and brown, which fades to delicate orange-pink when the bloom opens. Flowers are moderately large, semi-double, but very freely produced-the bush is almost always covered with buds and blooms. Strong, compact grower of branching habit. A very distinct variety in coloring, although flowers do not last long on the bush, they keep coming almost continuously.

One Year Plants. $40 \mathrm{c}$ each

Two Year Plants. $75 \mathrm{c}$ each

SOUVENIR DE CLAUDIUS PERNET-Very large, full flowers with long deep petals of the most striking sunflower-yellow, deeper in the center without color blending. Blooms early and late. When it has become established in your garden, its growth is strong and vigorous, with large brilliant glossy green foliage, which is disease-resistant. It is not easy to get started for like all yellow roses, it requires pampering, but is worth your greatest efforts. A beautiful glowing pure rich yellow which does not fade and certainly supplies the long-felt need in the garden.

One Year Plants 60c each

Two Year Plants $\$ 1.00$ each
SENSATION-A magnificent sweetly scented, velvety scarlet-crimson with deep maroon tints. Buds are long and pointed; flowers are enormous in size, of fine deep form, very double and composed of large, rich, velvety petals of wonderful substance. A sturdy grower, making heavy, strong canes, free branching with large, bold, dark green foliage. This rose is a tempermental bloomer under unfavorable conditions but is superb in the garden when conditions are ideal and in autumn waxes a marvelous blackish-red.

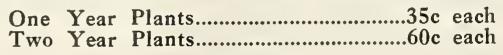

REV. F. PAGE ROBERTS-A glorified Duchess of Wellington, with more petals, better shape, and deeper, richer color. Coppery red buds of wonderful size and length, open into golden-yellow flowers, which are very, very double. The plant grows vigorously, with magnificent healthy foliage and branches freely. A supremely gorgeous Rose, developing to surpassing magnificence in size, color and fragrance, especially in cool weather, or in early autumn.

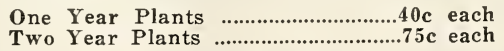

SOUVENIR DE GEORGES PERNET-Rich oriental red, shaded with yellow; ends of petals terra-cotta pink. Stocky, dwarf plant with dark bronzy-green foliage. Very vigorous, upright, and bushy; extremely hardy. Like other roses produced by Pernet, it resents too close pruning but is immune to mildew. Buds and flowers are very large, borne on long, strong stems. An unusually beautiful Rose, particularly adapted for massive bedding effects.

One Year Plants.......................................50c each

Two Year Plants................................\$1.00 each

THERESA ZEIMET LAMBERT-A most striking variety having wonderful long buds of fine, heavy texture and full, double, high-centered flowers. Deep rose-pink with yellow ground, orange at base, forming a very unusual combination. Very hardy and while it blooms profusely, this is done intermittently and not continuously. Unusually attractive in form and color, with long stems suitable for cutting.

One Year Plants

$.35 \mathrm{c}$ each

Two Year Plants

$60 \mathrm{c}$ each

\section{Special Offer for These Varieties}

Your Choice of Any Three Assorted One Year Plants for $\$ 1.00$ Your Choice of Any Three Assorted Two Year Plants, \$2.00

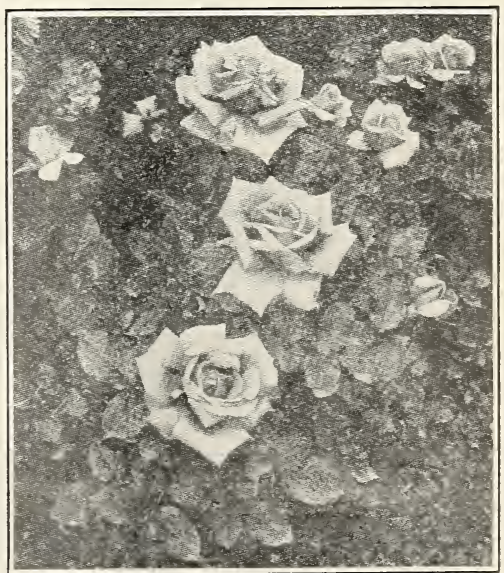

Souv. de Claudius Pernet 


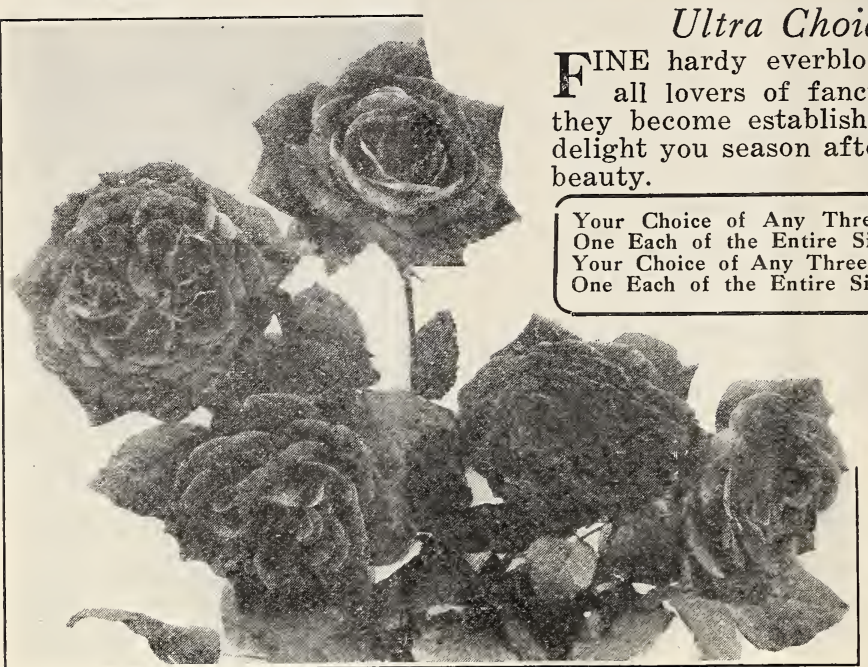

Royal Red-Wonderful New Intense Crimson
EDEL-An enormous, bold, stately, well built flower of great depth, quality and finish. Warm ivorywhite, of lovely globular form with a faint and pleasing fragrance. Very free flowering, growth most robust with strong erect stems and ornamental foliage. Decidedly hardy; it is a superb sort for garden effect.

One Year Plants.....................................35c each

Two Year Plants........................................60 each

LOS ANGELES-A rose that wins its way to the heart of every observer. It produces a continuous succession of long-stemmed flowers of a luminous flame-pink, toned with coral and shaded with translucent gold at the base of the petals. The buds are long and pointed and expand into immense flowers that are beautifully formed and possess an intense fragrance of pure deliciousness.

One Year Plants...................................40 each

Two Year Plants.......................................75c each

Ideal Collection for Rose Lovers

These Roses will prove a constant source of delight, blooming the entire season.

Six Fine One Year Old Plants for.

$\$ 1.00$

Six Strong Two Year Old Plants for ......... 2.25

Golden Ophelia-real golden yellow.

Hoosier Beauty - a deep crimson-scarlet.

Mme. Butterfly-pink tinted apricot.

Mrs. H. R. Darlington-large creamy white.

Radiance-rich glowing pink.

Red Radiance-dazzling rich red.
ROSE MARIE-Fragrant, clear rose-pink flowers of large size and exquisite shape, borne freely on plants of remarkable vigor and health. A quite distinct variety in coloring, proving delightful for the garden.

One Year Plants

.35 c each

Two Year Plants......................................60 each

ROYAL RED-A new intense crimson-scarlet of the richest coloring and texture. Blooms are enormous in size, very full and as double as a Rose can be. Buds and flowers are wonderfully formed, borne on long strong stems very profusely. It possesses a most delightful June-rose fragrance, growth is vigorous and compact with abundant large dark-green, leathery foliage and almost thornless branches. While this variety has not been tested out thoroughly in the garden, it has the vigor and sturdiness to prove a delightful acquisition.

One Year Plants. $40 \mathrm{c}$ each

Two Year Plants. $75 \mathrm{c}$ each

SOUVENIR DE H. A. VERSCHUREN-The glorious new two-toned yellow. Beautiful, rich apricot-yellow shading to saffron-yellow. Its vigorous growth, very free habit of flowering and ability to resist rose diseases under unfavorable weather conditions, places it among the best bedding varieties for the garden. The buds are long, of ideal shape, opening into full double flowers, having an intensely sweet tea fragrance.

One Year Plants $.35 \mathrm{c}$ each Two Year Plants
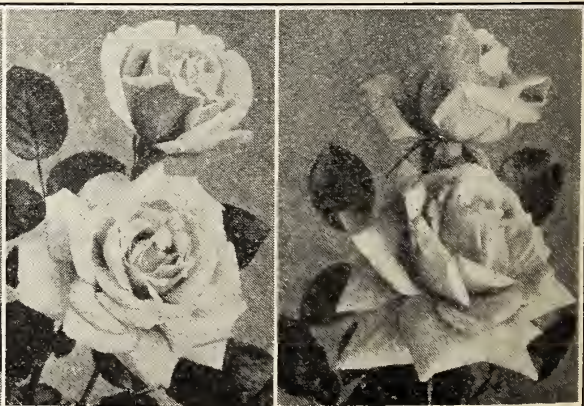


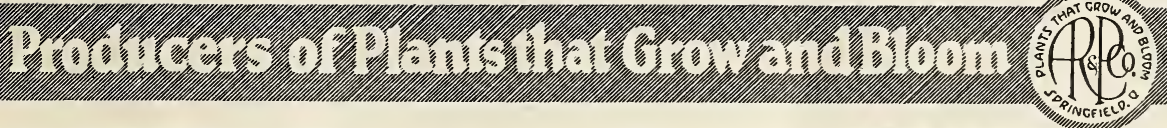

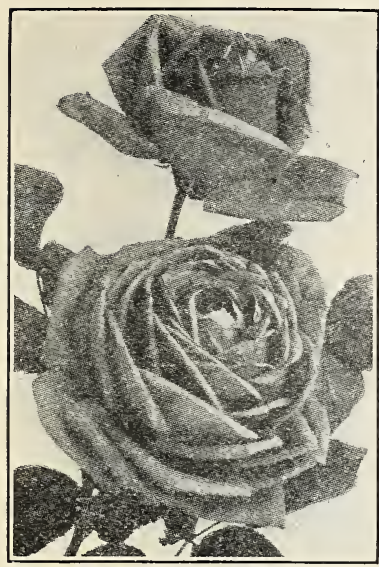

Francis Scott Key

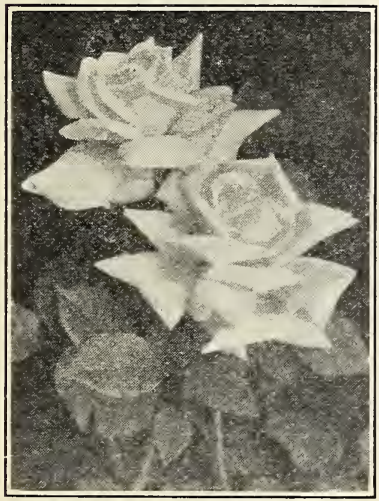

Mrs. H. R. Darlington
MRS. AARON WARD-One of the most beautiful roses in existence. Strong, hardy grower, bearing large, full, cupped flowers. Everyone loves the color which is coppery-orange shading goldenorange.

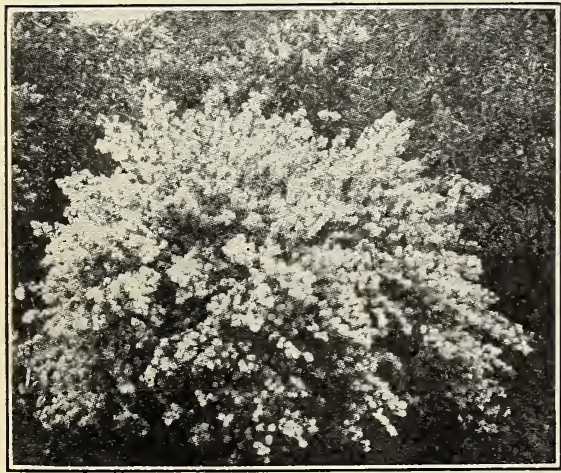

Deutzia Lemoinei

\section{Choice Hardy Everblooming Roses}

WITHOUT question the most valuable and popular class of roses today, superseding all other classes for general planting. In this group will be found varieties for every place and purpose; some of the most remarkable of the whole rose family are named.

Fine One Year Plants.............30c each Your Choice of Any Five for $\$ 1.00$ Entire List of Eight for ............. 1.50 Large Two Year Plants..........60 c each Your Choice of Any Four for $\$ 2.00$ Entire List of Eight for.............. 3.25

COLUMBIA-Enormous, full and perfectly formed fragrant flowers of clear rose pink, borne on nice, stiff stems; unequaled for cutting. Growth is vigorous and bushy and a most prolific bloomer. Ideal for the garden.

COMMONWEALTH - A magnificent new variety having large, long-pointed buds with open, double flowers of great lasting substance. Deep lively uniform pink color and delicate fragrance. Robust, upright grower. Particularly good during the Fall months.

FRANCIS SCOTT KEY - Very large and double, light crimson buds and blooms of noblest form; slightly fragrant. Plant makes vigorous erect growth, producing its massive blooms in great abundance; fine foliage and decidedly hardy. In cool weather, a perfect and glorious rose.

MME. CAROLINE TESTOUTLuxuriant grower, producing a profusion of lovely flowers of a

deep satiny rose, deepening to clear red in the center. A favorite bedding variety, perfect in growth and abundance of flowers.

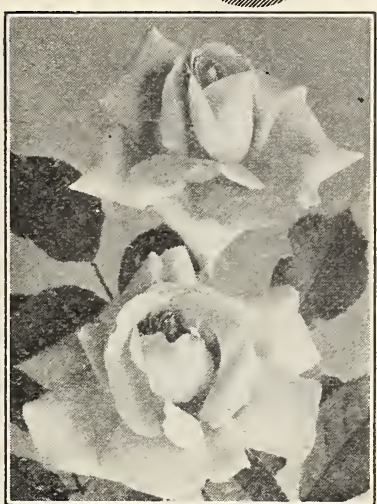

Mme. Caroline Testout

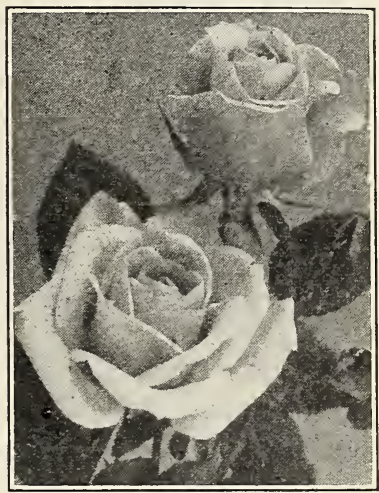

Commonwealth
MRS. H. R. DALLINGTON-An ideal creamy-white rose with very large, long buds of faultless form and full double flowers. Growth vigorous and upright with handsome green foliage. The best white bedding variety to date.

RED RADIANCE-Color brilliant dazz'ing crimson. A strong, sturdy grower having wonderful vitality. (See Illustration Page 2).

SUNBURST-Immense in size, the color is an exquisite orange-copper and golden yellow, extremely brilliant. The splendid flowers, borne on stiff, upright stems, are produced in amazing profusion.

\section{Deutzia Lemoinei}

A small shrub with spreading branches, usually about 3 feet tall, clothing itself with bright, green leaves, 2 to 3 inches long.

Very early bloomer, producing an abundance of pure white flowers in panicles on stout branches. It is extremely floriferous and ornamental, making possible many striking effects in garden or border; especially desirable for hedge purposes with its showy mass of exquisite flowers and its symmetrical, almost round form.

of easy culture and entirely hardy, it thrives in any good garden soil.

Fine, Large, Field-Grown Plants, $75 \mathrm{c}$ each, or 3 for $\$ 1.75$. 


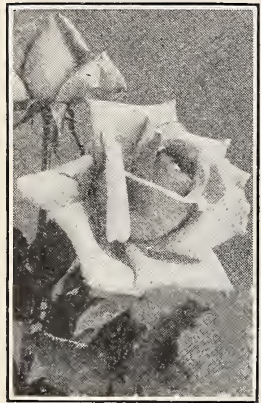

Jon. J. L. Mock

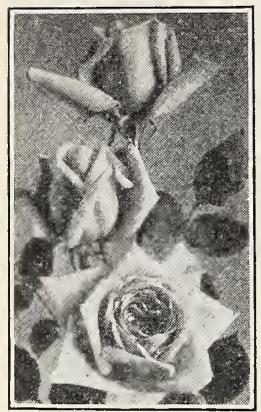

Mrs. A.R. Waddell

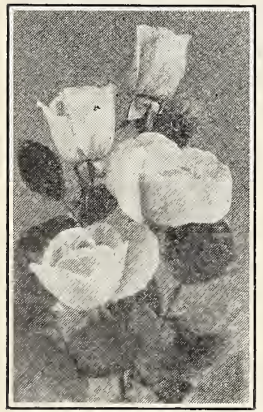

Mme. Butterfly

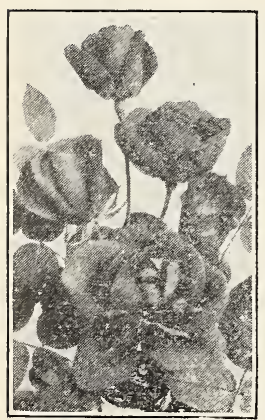

Gen. MacArthur

Page Six

\section{A Planting of Our Special Selected Varieties From Our Maine to California Rose Trail}

$\mathrm{F}^{\mathrm{ROM}}$ Coast to Coast, no matter where you live, they form magnificent plants, thriving vigorously and blooming with the utmost lavishness all summer through and making strong, sturdy bushes which last for years. They have every requisite necessary to perfect roses; sturdy habit of growth, ornamental foliage, exquisite flowers, delicious fragrance, constancy and freedom of bloom.
Fine One Year Plants, 25c each. Your Choice of Any 6 for $\$ 1.00$. Entire List of 14 for $\$ 2.00$.
Fine Two Year Plants, 50c each. Your Choice of Any 5 for $\$ 2.00$. Entire List of 14 for $\$ 4.50$.
ALEXANDER HILL GRAY-A delightful, exquisite lemon-yellow, deepening and intensifying as the blooms develop. Strong, vigorous grower with an abundance of large double buds and flowers.

ANGELUS-Color is a pure pearly white. A big, rounded rose, very full and quite double, unfolding into a massive flower borne on long regal stems. Vigorous, upright grower; free bloomer.

COLUMBIA-Enormous, full and perfectly formed flowers of clear, rosepink borne on nice stiff, upright stems; unequaled for cutting.

GENERAL MacARTHUR-One of the most brilliant reds (of all Everbloomers). Flowers are large, full and fragrant, produced constantly from early Spring until late Spring.

GOLDEN OPHELIA-A real goldenyellow without a tinge of any con trasting color. Vigorous grower, bearing an abundance of perfectly formed, deliciously fragrant flowers on stiff, heavy stems.

GRUSS AN TEPLITZ-Flowers are large and full of the brightest crimsonscarlet; fragrance is delicious and lasting. No other rose to compare with it in freedom of bloom.

HOOSIER BEAUTY-Glowing crimsondazzling in its velvety brilliance. Long pointed buds with beautiful notched petals of marvelous substance. Must be given some special care to get it established in the garden. scarlet with darker shadings, quite

JONKHEER J. L. MOCK-Full double flowers of brilliant carmine-rose on outside of petals, turning silvery-rose toward the center. Wonderful garden variety.

KAISERIN AUGUSTA VICTORIA-A continuous bloomer of full, double flowers which are a creamy white, slightly lemon-tinted near the center.

KILLARNEY-The magnificent sturdy habit of growth, beautiful foliage, delicious fragrance and deep brilliant, sparkling pink flowers make this one of the most beautiful and popular roses ever produced.

MME. BUTTERFLY-A perfect harmony of bright pink, apricot and gold Buds are medium in size, perfect for corsages, while the open flowers are lovely in form, texture and fragrance.

MRS. A. R. WADDELL-A superb garden variety. Marvelous bloomer, having deep apricot-yellow, orange and salmon flowers. Buds are long and pointed.

RADIANCE-A brilliant blending of carmine-rose with opal and coppery reflections, extremely brilliant in effect. Fine hardy bloomer unequalled for bedding and cutting.

ROBIN HOOD-Medium size, full blooms of rosy scarlet, becoming crimson in cool weather. Wonderfully fragrant. Growth is moderately vigorous, with particularly attractive foliage. A very prolific bloomer.

Macon, Ga., April 30, 1926

My Rose Bushes were received and in perfect condition.

I shall always hold you in esteem and shall give you more orders as soon as time is most convenient for me to do so.

Assuring you of my highest regard for your prompt service, I beg to remain,

CLEO B. CAMPBELL.
Middletown, Ohio, April 27, 1926

Roses received in fine shape. Many thanks for extras. Surely appreciate same. Also wish to state that they were the nicest, healthiest looking bushes that I ever bought.

Also learned a great deal from your circular. Many plants that I have bought in the past were just some as you stated not worth the time and trouble to plant and I got stung on a great many. 


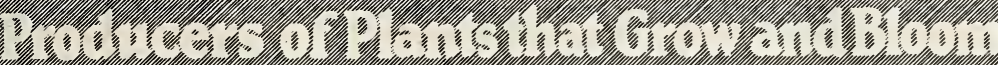

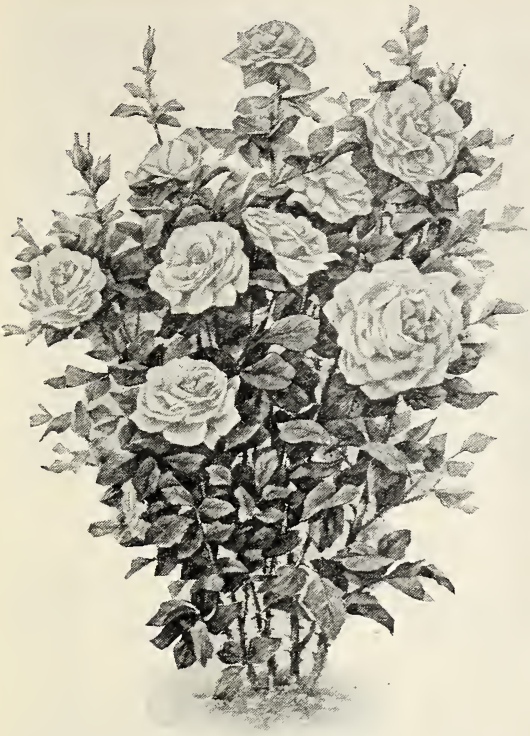

American Beauty

Results obtained with our extra large rose bushes

DR. VAN FLEET-Lovely pink climber. EMILY GRAY-Gorgeous clear yellow climber. GARDENIA (Hardy Marechal Niel)-Yellow. GRUSS AN TEPLITZ-Rich dazzling scarlet. JONKHEER J. L. MOCK-Silvery rose. MAMAN COCHET-Deep soft rosy-pink. MARY WALLACE-Rose-pink with salmon tints. MME. BUTTERFLY-Bright pink, apricot and gold.

\section{Hypericum Moserianum}

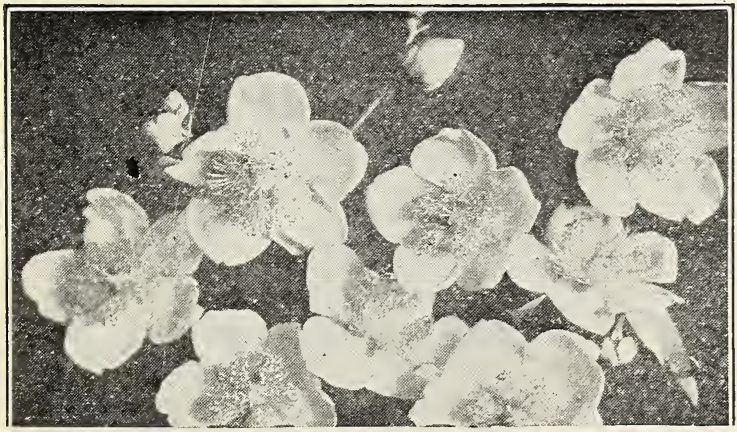

Flowers are Very Showy and Handsome
Springfield, Mass., April 27, 1926. I received the order of Roses which I sent you March 29th and I thank you for your prompt attention and the fine plants which you sent. I have never seen better ones,

I am enclosing check for the list of fourteen varieties of Peonies which you advertise as special trial offer.

MRS. F. P. NUTTING.

\section{Extra Large Roses}

\section{Special Field Grown Finished Bushes}

MANY of our customers have asked for Extra Large Finished Rose Bushes which would give them immediate effect, so to meet this demand, we have produced the following kinds. They are thrifty, sturdy plants with large, heavy branches and strong, vigorous roots, demonstrating remarkable energy, adaptability and tenacity of life. They may be depended upon for an abundance of flowers with good foliage effect the first season.

Price, $\$ 1.00$ Each

Your Choice of Any 6 for $\$ 5.00$

AMERICAN BEAUTY-Rich rosy-crimson.

CLIMBING AMERICAN BEAUTY-Rosy-crimson.

COLUMBIA-Clear rose-pink.

OPHELIA-Rose tinted salmon-orange.

PAUL'S SCARLET CLIMBER-Deep crimson climber. PEACE-Rich creamy-white.

RADIANCE-Clear carmine-rose.

RED RADIANCE-Brilliant crimson-scarlet.

ULRICH BRUNNER-Rich cherry-crimson.

WHITE AMERICAN BEAUTY-Pure white.

YELLOW KILLARNEY-Brilliant saffron-yellow.

\section{"Gold Flower"}

A GAY and showy plant admirably adapted A for border planting, either as a specimen or in masses. Growth is very vigorous but only attaining a height of two to three feet, so that it fits in the foreground of taller growing shrubs, or is ideal where a lowgrowing background is needed. It is of very free and graceful habit, producing long, slender, much branched stems, leafy to the base. It is marvelously free flowering, bearing all summer a profusion of waxy, clear, yellow flowers like roses. The foliage is very ornamental, deep rich green of heavy leathery texture.

Special Offer-Fine, Strong Plants, 50c each; Three for $\$ 1.00$.

Greenville, Pa., February 21, 1926.

Please send me a copy of your Spring Catalog for 1926. I have bought your Roses and they are the best I can get for the money and then some. There is no comparison between your Roses and other firms' Roses so greatly advertised. I tried some and I know. I want some more of your Roses this Spring. MRS. W. H. CREESE. 


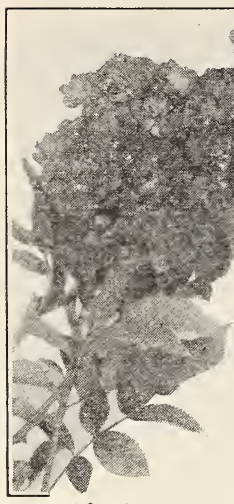

Ideal

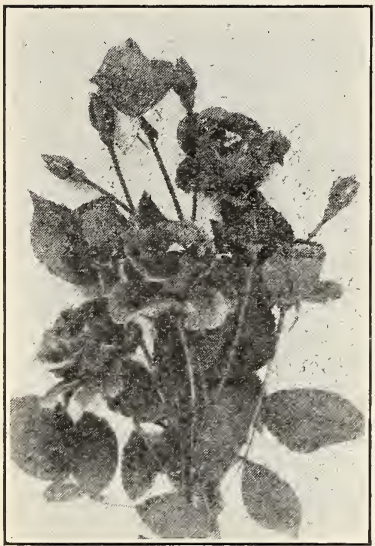

Lafayetie

\section{Hardy Polyantha or Baby Roses}

\section{Plant for a Continuous Mass of Bloom}

TDEAL for bordering beds, edging walks and planting in solid masses; they surpass all others in continuous bloom-

ing qualities from early Spring to late Fall. Entirely hardy and especially adaptable for cemetery planting, where they must withstand the most unfavorable weather conditions without care or attention.

The Entire List of 5 in fine One Year Plants for $\$ 1.00$

The Entire List of 5 in Large Two Year Plants for $\$ 2.25$

CATHERINE ZEIMET (Double White Baby Rambler)-A most beautiful companion to Ideal; growth rapid and sturdy and a free bloomer of great masses of double, pure white, glistening flowers, which are delightfully fragrant. Fine for bedding or potting purposes.

One Year Plants........................25c each

Two Year Plants..........................50 each

GEORGE ELGER-The first pure yellow introduced of its class. Erect growth with smooth reddish wood and brilliant, dark green foliage, brown underneath. Dainty pointed buds and beautifully formed flowers in big clusters, golden coppery-yellow, passing to clear yellow when expanded.

$$
\text { One Year Plants........................25c each }
$$

Two Year Plants.........................50 each

IDEAL-The darkest and most striking colored of all baby roses; an intense, rich, lustrous garnet. The medium-sized flowers are produced in very large trusses, in the greatest profusion. Growth is very compact but rapid.

One Year Plants........................... $35 \mathrm{c}$ each
Two Year Plants.....................75c each

LAFAYETTE - A variety for massing, or wonderiully effective as a single specimen. A decidedly distinct type as the brilliant cherry-crimson flowers of immense size are produced on great branched trusses (as many as forty flowers on one branch). The largest flowering Polyantha yet produced.

One Year Plants.........................35c each

MLLE CECILE BRUNNER (Sweetheart)-The most charming of all the exquisite Polyantha roses, frequently called "Sweetheart" by flower lovers. The full, double flowers are borne profusely; the color is a soft blush pink, deepening to rose.

One Year Plants.........................25c each

\section{The New Dooryard Roses}

T

HESE two productions of Dr. Van Fleet, the famous rosarian, represent a decidedly new type. The chief characteristics are glossy, dark green foliage, resistant to mildew and black-spot and proving very ornamental the whole season through. The growth is vigorous and robust, of marked hardiness, and by severe pruning a beautiful shrub of graceful spreading habit can be obtained.

HEART OF GOLD is freely produced in immense clusters, carrying as many as 75 flowers in a panicle. These flowers are $3 \frac{1}{2}$ to 4 inches in diameter, rich dark purplish-crimson in color, with a white base and a mass of golden yellow stamens.

MARY WALLACE is bright rose-pink with salmon base. Fragrance is delightful. Buds are long and pointed, developing into very large semi-double, cupped flowers, borne several together on long stems, which have few thorns. A marvelous pillar rose of vigorous climbing habit.

Fine One Year Plants, 35c each; or one each for 50c

Large Two Year Plants, 50c each; or one each for $85 \mathrm{c}$

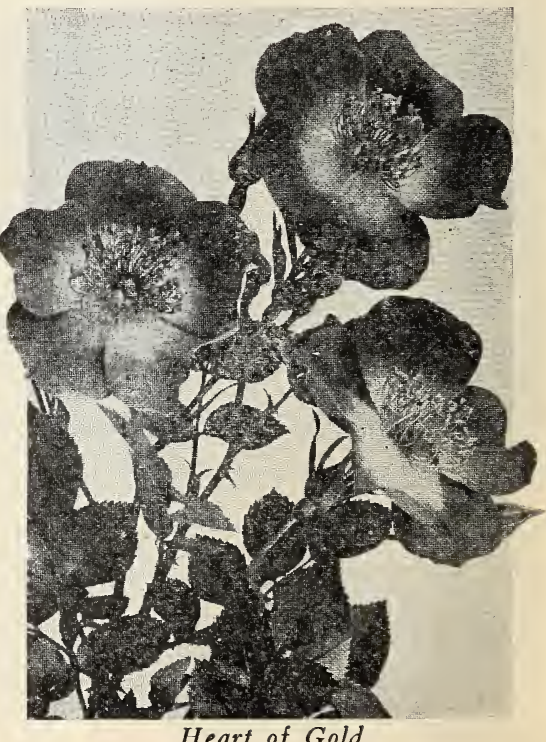




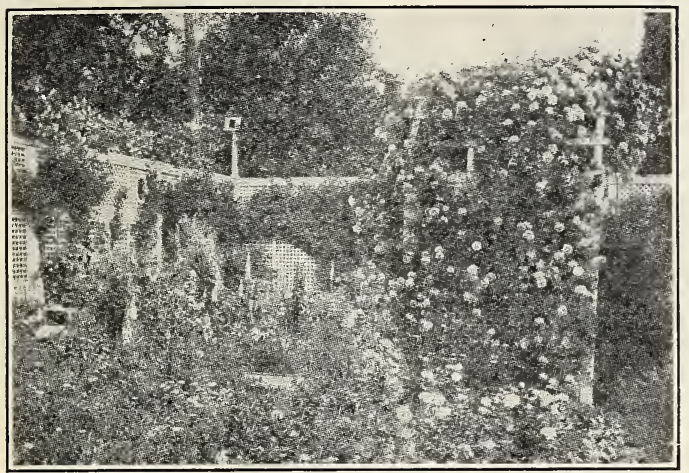

Seclusion and Beauty with These Magnificent Climbing Roses

CLIMBING AMERICAN BEAUTY-Rosy-red.

DR. W. VAN FLEET-Delicate flesh pink.

SILVER MOON-Pure waxy white.

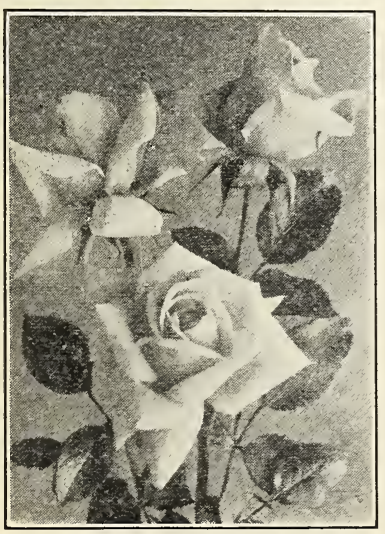

Pink

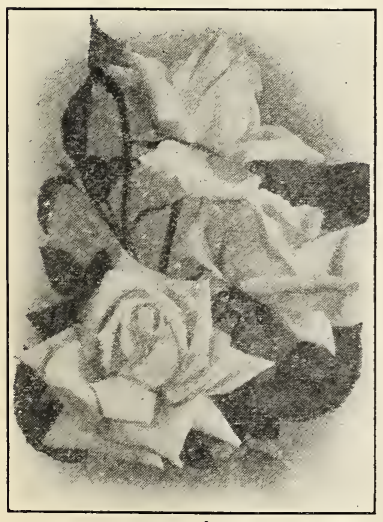

White

\section{Glorify Your Garden} With Roses Like These

F you want to cut an llabundance of beautiful, fragrant, dewy roses every day from early spring to late fall, plant this assortment of the ever-popular and gorgeous Cochets. They have remarkably vigorous growth, handsome, fresh, green foliage and may be grown successfully in any good garden soil. The flowers are large, bold, full and double, of exquisite rich colors and all possess delicious fragrance.

Fine One Year Plants, 25c each or the Four for $65 \mathrm{c}$.

Large Two Year Plants, 50 each, or the Four for $\$ 1.35$.

PINK MAMAN COCHET-Deep, soft rosy-pink, uniform in color. Buds are full, firm and pointed; flowers are extra large and perfectly double.

RED MAMAN COCHET-Bright, rosy-red flowers, shaded deep crimson. Fine, large buds and lovely, full flowers with beautiful reflexed petals.

WHITE MAMAN COCHET-A marvelous bedding kind, which produces ideal flowers for cutting; full and double, of dainty white, sometimes tinged pale blush.

YELLOW MAMAN COCHETLong, pointed buds and large, shapely flowers of deep lemonyellow.

\section{Roses}

For Massing and Cutting

Year Plants Delivered to

Two Year Plants Delivered to

ew type of climbing rose will prove a 1 revelation to those who do not already know them. Beautiful, large fragrant flowers borne on long, individual stems and having delicious

If you want a magnificent rose hedge, arbor pergola, summer-house, or porch screen, this is vation. Hardy Marechal Niel)-Yellow.
RLET CLIMBER-Deep crimson.

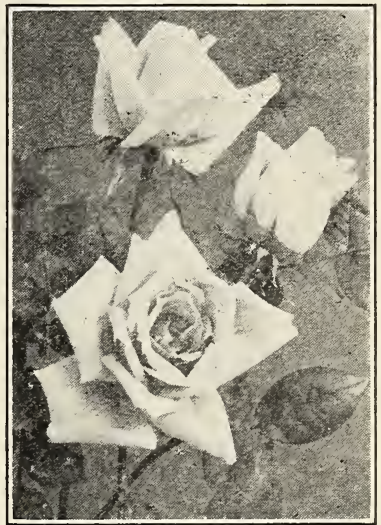

Yellow

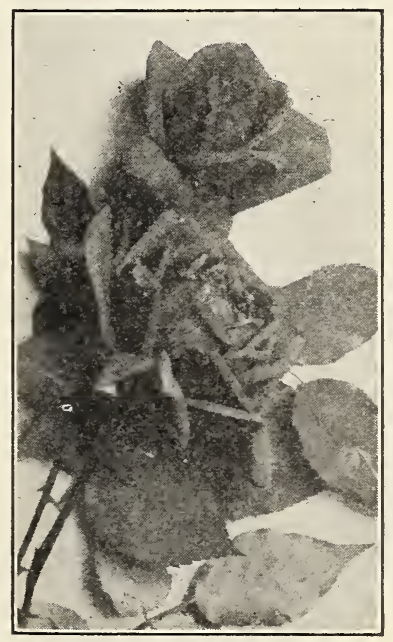

Red 


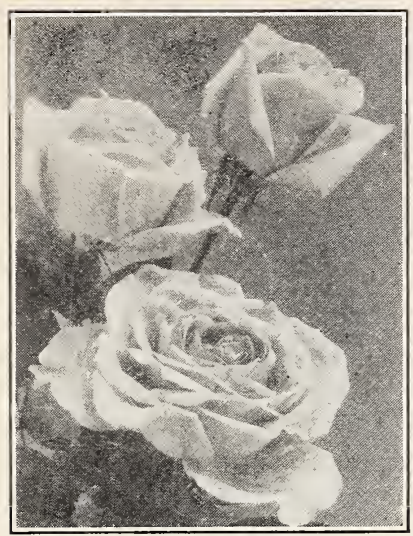

Pink American Beauty

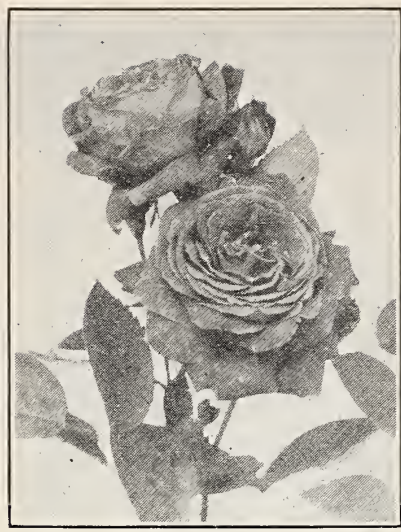

Black Prince

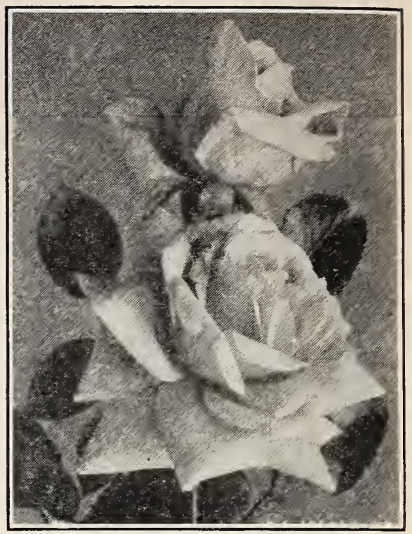

White American Beauty

\section{Hybrid Perpetual or June Roses}

WERY valuable for permanent planting, as they flourish over a wider range of latitude and thrive under more varying conditions. Frequently called "June roses," as a most notable crop of bloom is produced in early summer; showy flowers of enormous size, the most brilliant colors and the sweetest fragrance.

Fine One Year Plants-One each of Five for $\$ 1.00$

Large Two Year Plants-One each of Five for $\mathbf{2 . 2 5}$

AMERICAN BEAUTY-Known the world over for its magnificent, large, glowing crimson flowers. Foliage large, leathery; hardy in all sections; it produces a constant profusion of massive, rich, fragrant bloom.

Fine One Year Plants, 30c each.

Large Two Year Plants, 75c each.

BLACK PRINCE-Extremely hardy, producing a profusion of deep, blackish-crimson flowers. Buds and flowers are large, full and globular.

Fine One Year Plants, 25c each.

Large Two Year Plants, 50c each.

PAUL NEYRON-A beautiful, clear rose-pink, immense in size, sometimes measuring six inches across. A strong, upright grower and an abundant bloomer.

Fine One Year Plants, 25c each.

Large Two Year Plants, 50c each.

PINK AMERICAN BEAUTY-Bright rose-pink of great richness and uniformity. Large pointed buds developing into full double flowers having delightful fragrance. Exceptionally free bloomer and vigorous grower. A superb variety.

Fine One Year Plants, 30c each.

Large Two Year Plants, 75c each. BEAUTY - The best snow-white $\mathrm{R}$ os $\mathrm{e}$ ever produced, a single plant bearing hundreds of massive, charmingly veined, marvelously fragran t white flowers.

Fine One Year Plants, 30c each.

Large Two Year

Plants, $75 \mathrm{c}$ each.
WHITE AMERICAN

\section{Moss and Rugosa Roses}

TWO very desirable types, ruggedly hardy, vigorous 1 growers and prolific, fragrant bloomers. Moss roses are of unique beauty, the buds and stems showing the quaint mossy covering which distinguishes them. The Rugosa Hybrids have distinct and beautiful foliage with exquisite fragrant flowers, which are followed by large, brilliant red seedpods. They may be trained as shrubs, either in groups or single specimens.

Fine One Year Plants-One each of Five for $\$ 1.00$ Large Two Year Plants-One each of Five for \$2.25.

CONRAD F. MEYER (Hybrid Rugosa)-Very large, well built flowers of light silvery pink. A remarkable single specimen, with its splendid display of bloom.

Fine One Year Plants-25c each

Large Two Year Plants-50c each

ELIZABETH ROWE-A hardy and vigorous variety of bright, rosy-pink, sweetly fragrant and splendidly mossed. The flowers are extra large, full and double.

Fine One Year Plants-25c each Large Two Year Plants-50c each

F. J. GROOTENDORST (New Hybrid Rugosa)-An everbloomer producing great masses of huge brilliant orange-crimson trusses of flowers. Wonderful for shrubbery border or an everblooming hedge.

Fine One Year Plants-35c each

Large Two Year Plants-75c each

HENRI MARTIN-Deep carmine flowers shaded with bright crimson are produced in abundance. The buds are especially well mossed and the fragrance is delightfully sweer. One of the most beautiful and striking bold varieties.

Fine One Year Plants-25c each

Large Two Year Plants-50c each

MOUSSELINE-The best white Moss Rose. The large, full blossoms are the purest white with fine fragrance. Both buds and flowers are invested with a wealth of green moss and are produced almost constantly.

Fine One Year Plants-25c each

Large Two Year Plants-50c each

\section{Philadelphus Virginal}

Smells and Looks Like Orange Blossoms

MOST beautiful new variety, considered one of the finest introductions A of recent years. Vigorous and tall in growth, it is absolutely hardy and dependable to produce an amazing profusion of flowers year after year. It blooms in June and continues over a long period, producing flowers in dense clusters, large and double, pure white and sweetly scented. A cluster of these chastely beautiful, fragrant flowers resembles a bride's bouquet of orange blossoms. Justly called a "Grand Shrub" adding beauty, grace and perfume to every garden.
Philadelphus Virginal 


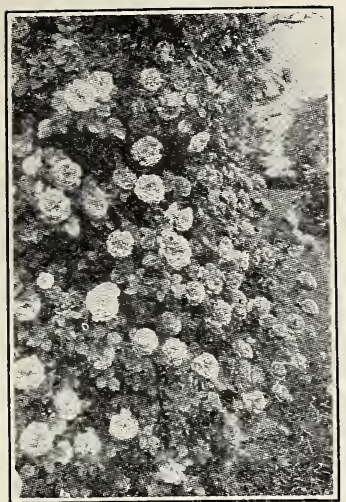

Climbing American Beauty

\section{Climbing Roses}

$\mathbf{T}$

HESE Roses are necessary for the home, particularly adapted for covering $\mathrm{p}$ or $\mathrm{ch}$ e s, pillars, fences and for screening undesirable views and buildings. They are hardy everywhere, excepting the Climbing Teas, which, in the North, must be protected to withstand the winters. This list comprises the most desirable kinds and will please all who plant them.

Fine One Year Plants, 25c each. Your Choice of Any Six for $\$ 1.00$. Large Two Year Plants, 50c each. Your Choice of Any Five for $\$ \mathbf{2 . 0 0}$.

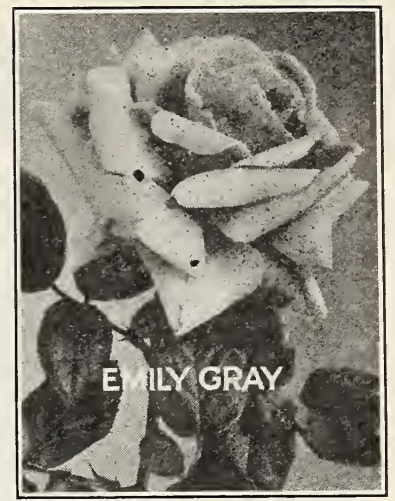

ALIDA LOVETT-A fine, new hardy variety, with large, glossy green, mildew-proof foliage. Strong grower and free bloomer, flowers produced on long stiff stems, of a lively, bright, shell-pink with shadings of rich sulphur at the base.

CLIMBING AMERICAN BEAUTY-A sturdy, vigorous variety, producing an abundance of vivid rosycrimson flowers in June and occasionally throughout the season, which possesses the same delicious fragrance as the old American Beauty. Perfectly hardy and immune to disease and insects.

CLIMBING KAISERIN AUG. VICTORIA-A strong, climbing pillar rose, having glossy foliage. Flowers creamy-white, faintly tinted lemon; large and free with a distinct magnolia-like fragrance; produced constantly on long, graceful stems.

CLIMBING LADY ASHTOWN-A true, everblooming climber. Exquisite flowers of pale carmine-pink, shading to golden-yellow at the base. Blooms are large, well-formed and deliciously fragrant; produced the entire season.

CLIMBING SUNBURST-Glorious orange-copper and golden-yellow flowers, identical with the bush form, but having a vigorous climbing growth, ideal for pillar or veranda use.

DR. W. VAN FLEET-An exquisite pink, deepening to rosy flesh. Large, fragrant flowers measuring over four inches in diameter are borne abundantly. Rapid, hardy grower with deep green foliage.
EMILY GRAY - The blooms are unusually large, borne on individual stems; very lasting; most gorgeous, c'ear yellow color, even the mature flowers becoming a pleasing ecru. The growth is strong and robust; foliage is thick and waxy, deep crimson when young, changing to deep green as they age.

GARDENIA (Hardy Marechal Niel)-Deep, rich, golden-yellow flowers, passing to creamy white. Blooms profusely and is hardy as an oak. Flowers large, making it fine for cutting.

MARECHAL NIEL-It is fairly riotous in growth, having an abundance of beautiful, thick, glossy foliage. It is universally claimed the most profuse bloomer of all climbers, single plants producing as many as two thousand blooms at one time. Color is faultless, the waxy petals showing rich, golden shades, the form of the bud perfectly rounded and luxuriantly massive in size.

MARY LOVETT-Size, shape and delicacy of the most exquisite tea rose. Large double creamy-white flowers borne in amazing profusion on individual stems; perfect for cutting.

PAUL'S SCARLET CLIMBER-No other rose can compare with it for brilliance of color, which is a vivid scarlet. The flowers are of medium size, semidouble, very freely produced in clusters of from three to six flowers each, the plants being literally covered with bloom. It is of strong climbing habit with wonderful glossy foliage.

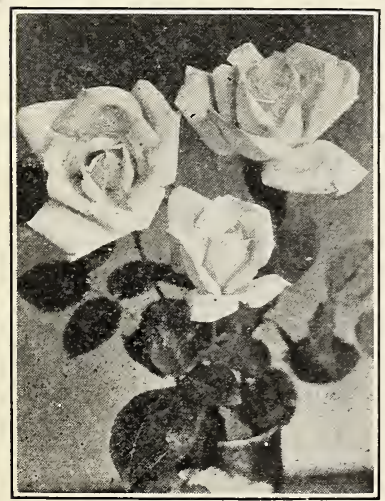

Mary Lovett
SHOWER OF GOLD-Well named, as the great clusters of deep, goldenyellow flowers entirely cover the plant. Hardy, sturdy grower with lovely, glossy foliage and of extremely free-flowering habit; blooms are very double and of heavy, lasting substance.

SILVER MOON-Sturdy, rapid grower, producing a wonderful profusion of extraordinarily large, Clematislike flowers, silvery-white in color, with bright golden-yellow stamens in the center.

TAUSENDSCHOEN-“Thousand Beauties." A strong grower with but few thorns; large clusters of double flowers, ranging from delicate pink to bright rose and carmine with white, yellow and various indescribable tints.

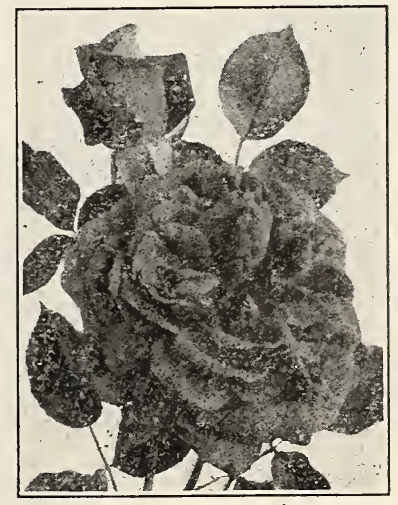

Paul's Scarlet Climber

Page Eleven 


\section{The American Rose antifin Co.}

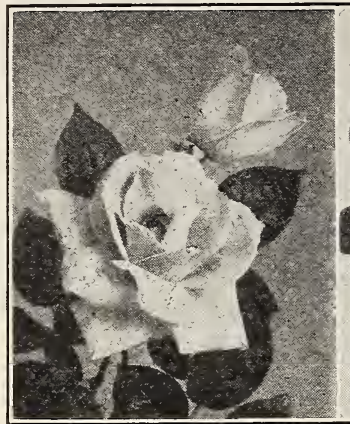

Lady Hillingdon

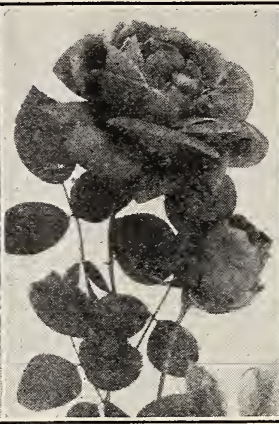

American Legion

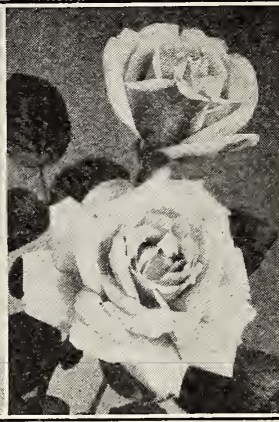

La France

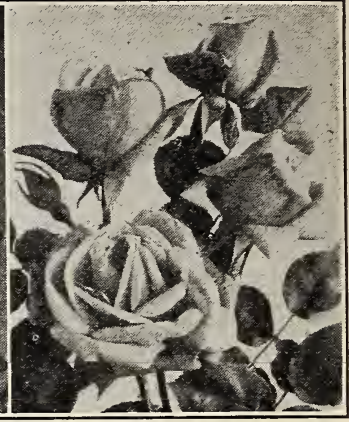

Ophelia

\section{Gems For Your Garden-To Bloom Every Month}

Y

OU may have fragrant roses in great profusion every month of the season with these desirable and beautiful varieties. They represent the choicest, dependable kinds, which have quality and a variety of charming colors that will be the pride of your Rose Garden.

Fine One Year Plants, 25c each.

Your Choice of Any Five for $\$ 1.00$.

Entire List of Nine for $\$ 1.50$.

AMERICAN LEGION-Pure cerise red throughout. Heavy, lasting texture, which is retained as the flowers open and a glorious satiny sheen over all that fairly glows.

CRUSADER-A brilliant velvety crimson. The blossoms are gorgeous, with delicious fragrance. Produced freely; of perfect formation.

DOUBLE WHITE KILLARNEY-The buds are exquisitely long and pointed, unfolding broad waxlike petals into enormous pure snow-white flowers.

LADY HILLINGDON-Slender pointed buds and elegantly cupped flowers of deep saffron-yellow. Erect grower with perfect foliage but requiring careful protection. Free flowering and lovely for cutting.
Large Two Year Plants, 50c each.

Your Choice of Any Four for $\$ 1.50$.

Entire List of Nine for $\$ 2.75$.

LA FRANCE-Color a lovely soft, silvery pink. Flowers and buds are long and wondrously beautiful, possessing the delicious La France fragrance.

MME, SEGOND WEBER-Vigorous grower, producing a profusion of large, perfectly formed cup-shaped. fragrant flowers, of marvelous beauty. Color is a lovely salmon-pink.

OPHELIA-The queen of fancy roses. Color is delicate salmon-orange, tinted rose; buds and flowers are unusually attractive; very fragrant.

RICHMOND-Crimson-scarlet buds and flowers of good size and form, with the real Damask perfume. Growth is moderately strong and very free flowering. A splendid cutting rose.

YELLOW KILLARNEY-A brilliant saffron-yellow rose, opening canary. Long, pointed buds, beautiful in form and color; flowers are large with immense petals.

\section{An Ideal Planting for Garage and Back Yard \\ 15 Fine Shrubs and Roses Delivered to You For \$2.50}

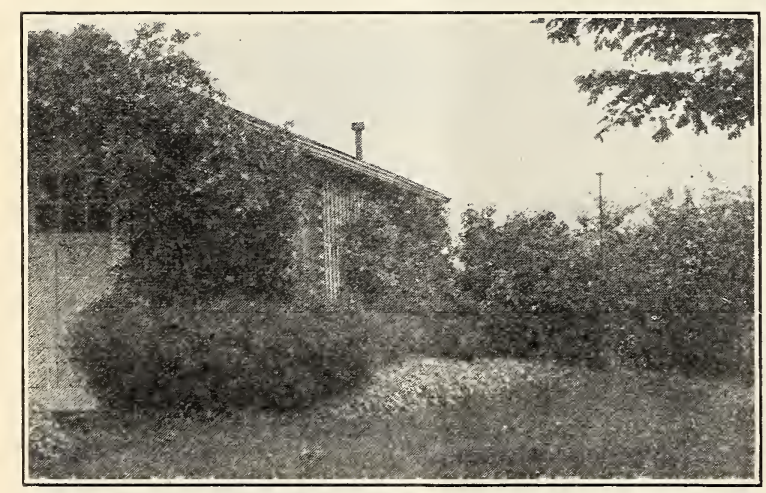

You Can Make Your Back Yard and Garage Look Like This
LL hardy, robust growers to give you delightful foliage and attractive flowers from early spring to late fall.

1 Climbing American Beauty Rose-Rosy-red.

1 Gardenia Rose (Hardy Marechal Niel)Golden yellow.

1 Althea Shrub (Rose of Sharon).

2 Barberry Thunbergi Shrubs (Japanese).

1 Deutzia-Large flowering white shrub.

1 Forsythia Shrub (Golden Bell).

1 Philadelphus Coronarius Shrub (Mock Orange).

2 Spirea Anthony Waterer Shrub (Everblooming red).

2 Spirea Van Houttei Shrub (Bridal Wreath).

3 Hardy Pinks (Gladys Cranfield) for border. 


\section{Producers of Plantsthat Grow and Blouin}

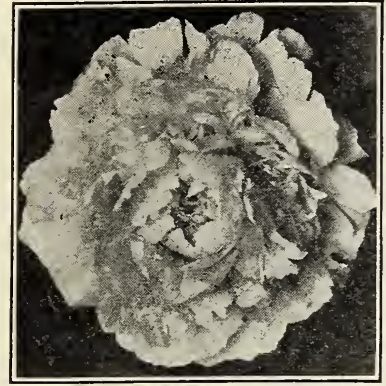

Sarah Bernhardt

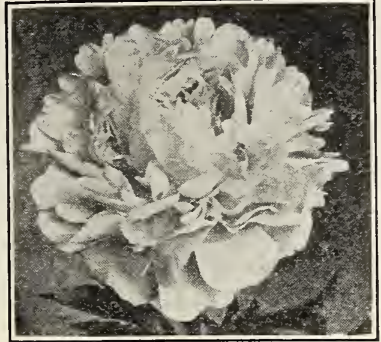

Mme. Emile Lemoine

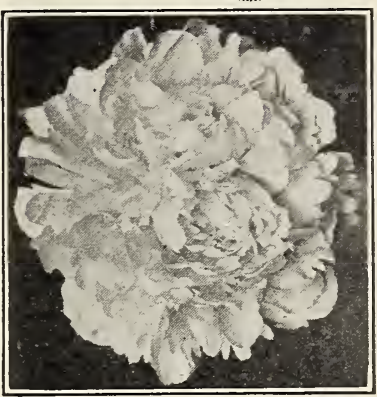

Albert Crousse

\section{Double Herbaceous Peonies}

W $\mathrm{E}$ know you will be pleased with these vigorous, clean roots, which have big, plump eyes that assure success: they may be depended upon to produce strong, thrifty growth the first season planted.

They will increase in size and beauty each succeeding year, requiring no care or attention.

\section{Special Offer-Entire List of 15 Varieties for $\$ 7.00$}

Your Choice of Any 4 in this list for $\$ 1.50$. Entire List of 7 for $\$ 2.50$.

ALBERT CROUSSE-Large well-formed flowers of soft shell-pink with faint salmon tints. Vigorous grower with tall, erect stems. Splendid for cut flowers. 75c each.

EDULIS SUPERBA-Very early, known as the Decoration Day Peony. A wonderful clear mauve-pink with silvery reflex. 50c each.

FELIX CROUSSE-The best red variety. Abundant bloomer, vigorous grower, large, globular flowers. Brilliant red color, with wonderful fragrance. $75 \mathrm{c}$ each.

FESTIVA MAXIMA-Very large, globular flowers, pure white center flecked crimson. Tall, vigorous grower, free and early bloomer. 50c each.

GERMAINE BIGOT-A fine, midseason blooming variety; very large and compact. Delicate lilac-rose, center prominently flecked crimson. Strong, erect grower, very free flowering and fragrant. 75c each.

MARIE STUART-Delicate lavender, flecked crimson, changing to a warm white, faintly tinted crimson. $75 \mathrm{c}$ each.

SUZETTE-Fine blooms borne on strong stems. Bengal-rose, lightly shaded carmine-purple with silvery reflex. $75 \mathrm{c}$ each.

Linlithgo, N. Y., April 19, 1926. I received the fourteen Rose Bushes this A. M. I am so thoroughly pleased with them and the perfect condition they arrived in, I simply had to write and tell you about it.

I am delighted with them, they are such nice large plants and so nicely rooted.

I thank you for your prompt careful service. MRS. F. A. PATTEN.

Painesville, Ohio, April 23, 1926.

Received the Spirea and Hydrangea in first class condition and found them very satisfactory. ROBERT WALTON.

\section{Peonies to Color}

RED, WHITE, PINK at 35c each; 3 for $75 c$

\section{One Each of This List of Four for $\$ 3.00$}

BARONESS SCHROEDER-Immense globular flowers of perfect form, of great lasting substance, ideal for cutting. Rose type; produces profuse flesh-white flowers which change to pure white; has exquisite rose fragrance. Each, $\$ 1.25$.

CLAIRE DUBOIS-Rich, clear satiny-pink with glossy reflex. Large rose-like flowers produced treely. Spiendid for cutting. Each, $\$ 1.00$.

LORD KITCHENER-Very early, brilliant cherry-red; a most dazzling hue. Strong grower and free bloomer of charming rose type flowers. Each, $\$ 1.50$.

SARAH BERNHARDT-Semi-rose type; late midseason. Very large flower of perfect form, full and double, with each petal silver-tipped. Strong grower, free bloomer and very fragrant. Each $\$ 1.50$.

\section{One Each of This List of Four for $\$ 3.00$}

JAMES KELWAY-Very full, double flowers having delightful fragrance, are produced very early. Color rose-white, changing to milk-white, tinged yellow at the base of the petals. Strong, tall grower and free bloomer. Each, \$1.50.

MIDNIGHT-Very deep maroon colored flowers with metallic reflex. Large, semi-rose type blooms on long, stiff stems are produced freely in late blooming season. Each, $\$ 1.00$.

MME. EMILE LEMOINE-Rich glossy white, overlaid with a sheen of tender satiny-pink covered with minute lilac dots. Large globular compact flowers are borne in mid-season. Very beautiful, perhaps the finest white. Each, $\$ 1.00$.

REINE HORTENSE (Syn. Pres. Taft)-Enormous, compact, flat flower of soft flesh-color deepening to shell-pink. Well formed and very striking. Fine for cut flowers and usually blooms profusely just about Decoration Day. Each, \$1.50.

Detroit, Minn., April 13, 1926. Roses received $O$. K. in the very best condition. I am certainly very glad of them and I thank you ever so much. 


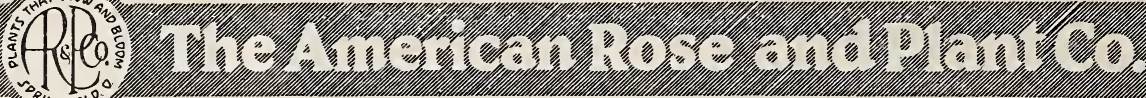

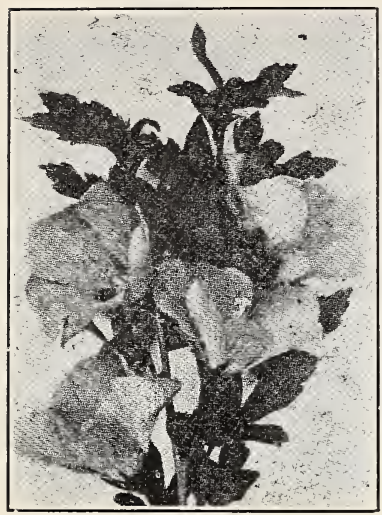

Althea (Rose of Sharon)

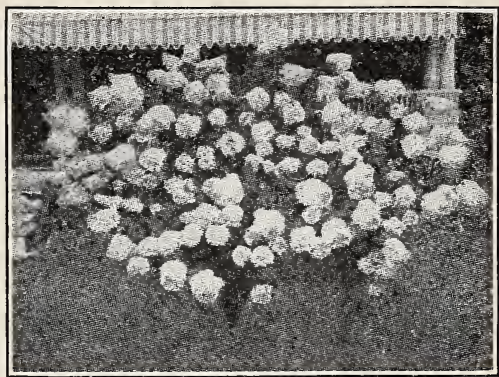

Hydrangea Paniculata $G r$.

Hardy Flowering Shrubs for Massing for Foundation Screens for Single Specimens

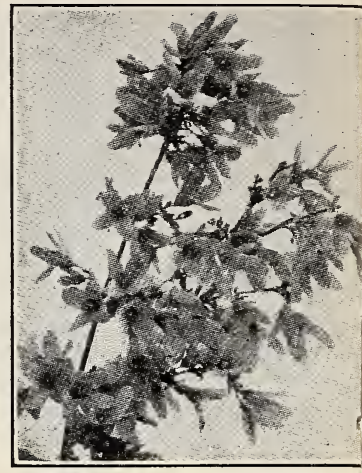

Forsythia (Golden Bell)

W HETHER planted individually or collectively, the shrub is an important feature in the adornment of any ground. At the edges of the lawn, along walks or drives, or in distant corners, a collection of shrubs may be gathered that will give a succession of bloom from the opening of Spring until frost comes to destroy the flowers.

In the list that follows will be found shrubs for all these purposes. The possibilities of effective combinations are unlimited. These are all strong, field-grown plants that will make well-developed specimens, giving immediate effect and will all bloom profusely this season.

ABELIA GRANDIFLORA (Broadleaved Evergreen)Just a few years ago this was thought to be a warm-climate plant only; today there are many fine specimens in northern gardens, and as it becomes known that it is hardy, it will be universally popular. From May till frost the graceful arching branches are covered with clusters of tubular-shaped white flowers daintly tinted pink. The leaves are small, lance shaped and glossy green with metallic sheen at the approach of winter. Useful as a specimen, for hedges, or in groupings for mass plantings around foundations or elsewhere. Ultimate height, $4 \frac{1 / 2}{2}$ to 5 feet, but if the long tender shoots are pinched back during the growing season, the plant becomes very dense and compact. It may be kept quite dwarf by trimming. 75c each.

ALTHEA BUSH (Rose of Sharon)-Double red, white and pink. Grand, free growing, flowering shrubs. Perfectly hardy. 'Very desirable as they bloom in August and September. Of easiest culture, fine for hedges or single specimens. 50c each.

AMYGDALUS ROSEA FLORE PLENO (Flowering Almond)-See detailed description page 24 . $75 \mathrm{c}$ each.

BUTTERFLY BUSH (Summer Lilac)-See detailed description page 24 . 50c each.
Spirea Anthony Waterer

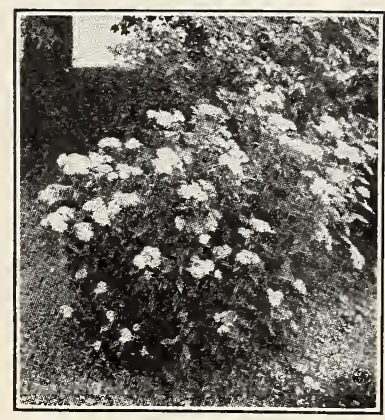

CORNUS SIBIRICA (Dogwood)-A hardy, vigorous shrub with upright, bright blood-red branches. Flowers are creamy-white in numerous, flat-topped clusters followed with light-blue fruit. $50 \mathrm{c}$ each.

CYDONIA JAPONICA (Scarlet Japanese Quince)One of the most brilliant flowering shrubs, covered with dazzling scarlet flowers very early in the Spring, followed by yellowish-green aromatic fruits about two inches in diameter. Bright green, glossy leaves and spreading compact branches. Very symmetrically-growing shrub, beautiful for specimens or will make an impassable hedge. 50c each.

DEUTZIA LEMOINEI-See detailed description page 5. 75c each.

DEUTZIA ROSEA-Showy, hardy and ornamental. Of easy cultivation and rapid growth, with a wealth of double, rosy-pink, drooping, bell-shaped flowers. $50 \mathrm{c}$ each.

FORSYTHIA VIRIDISSIMA (Golden Bell)-Large, graceful variety with a profusion of golden-yellow flowers produced early. Foliage narrow and very dark green. 50c each.
H Y D R A N G E A ARBORESCENS GRANDIFLORA ALBA (Hills of Snow)-Admirably adapted for border planting, either as a specimen or in masses. Growth is very vigorous and hardy, round and compact, usually attaining a height of from four to six feet, but may be trimmed to any desired height. Ornamental bright green leaves, starting to bloom after the passing of early-flowering shrubs, its value is enhanced. Flowers are produced in numerous flat-topped clusters of dazzling pure white. $75 c$ each

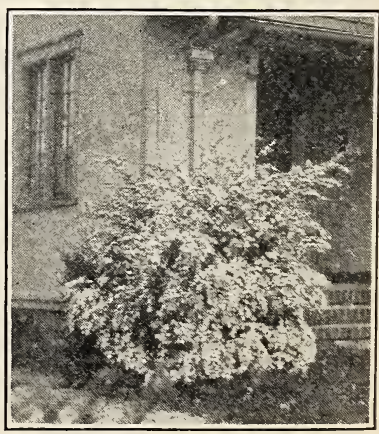

Spirea Van Houttei 


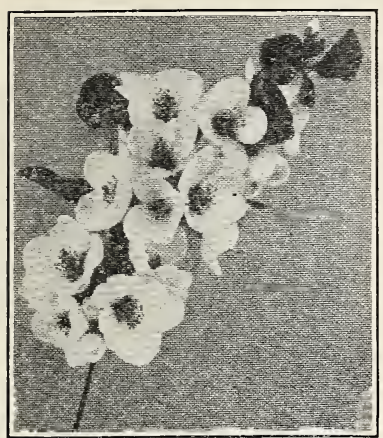

Cydonia Japonica

(Scarlet Japan Quince)

HYDRANGEA PANICULATA GRANDIFLORA-One of the most popular and showy shrubs, with large, rosy-pink, pear-shaped clusters of bloom. Handsome, dark-green foliage. 75c each.

LILAC PURPLE-Án old favorite. Produces an abundance of fragrant purple clusters of bloom. Upright, vigorous growth with heart-shaped, bright green leaves. $75 \mathrm{c}$ each.

LONICERA FRAGRANTISSIMA (Bush Honeysuckle)-A tall, vigorous grower, very hardy, with broad, oval foliage, which remains on the bush until very late Fall. Flowers are creamy-white or delicate yellow, deliciously fragrant, expanding with the first breath of spring. 50c each.

PHILADELPHUS VIRGINAL-See detailed description page 10 . 75c each.

PRUNUS PISSARDI (Purple-Leaved Plum)-A dwarf, slender grower, about three to four feet high, covering itself with small, white, fragrant flowers in early Spring. Foliage is a lustrous crimson when it first appears, but changes to a rich purple when matured. A most unusual and striking variety. $75 \mathrm{c}$ each.

SPIREA ANTHONY WATERER (Everblooming Spirea)-A remarkable free-flowering shrub with upright branches, attaining a height of about two feet. Very hardy and robust. Leaves are bright green and flowers bright rose, produced in dense clusters, blossoming throughout the summer. Especially desirable where dwarf or low-growing plants are wanted. This plant is fine for massing or for single specimens. $50 \mathrm{c}$ each.

RED SNOWBERRY-Has a wealth of red berries which remain on the branches all winter. Very hardy and vigorous, with bright-green leaves, often tinted with reddish-purple when young, persisting until early winter. Flowers, light-pink, produced in early summer. $50 \mathrm{c}$ each.

SNOWBALL (Opulus Sterilis)-Handsome, showy, globular clusters of flowers appearing in compact balls in early spring, tisually about Decoration Day. Very hardy and vigorous, growing to perfection in any sunny situation. 75c each.

SPIREA BILLIARDI (Pink) - Very showy and attractive, and splendid for cut flowers. Blooms bright-pink, produced in long, dense panicles, later in the summer than most Spireas flower. $50 \mathrm{c}$ each.

SPIREA THUNBERGI (Snow Garland)-A graceful, slender grower, forming a dense feathery bush three or four feet tall. Has an abundance of narrow, green leaves, which assume brilliant tones of orange and scarlet in the Fall. Flowers are pure white, covering the plant as with a mantle of snow. 50c each.

SPIREA VAN HOUTTE (Bridal Wreath)-Flowers are produced in such profusion in late spring as to completely cover the bush with masses of snow-white bloom. They are borne in large, spray-like clusters which resemble a wreath, hence its name "Bridal Wreath." Universally the most popular of all hardy flowering shrubs and certainly one of the most deserving. 50c each.

WEIGELA ROSEA-A free-flowering shrub, with numerous spreading branches. Flowers, rose colored, large and showy, produced in great profusion. 50c each.

WHITE SNOWBERRY-A popular, hardy shrub of medium size and bushy form. Foliage oval and smooth; soft pink flowers are produced in the summer, followed by large, waxy, white berries in Autumn, persisting into mid-winter. Very ornamental. 50c each.

\section{Hedge Plants}

1 LIVING fence, one made of plants, attractive with their green leaves, trained or arched branches, colored foliage or bright berries. A lawn hedge is permanent, only requiring occasional pruning or shearing.

BARBERRY THUNBERGI (Japanese)-A "Blaze of Glory" during the fall months with its abundance of brilliant, scarlet berries and attractive foliage of varied tints, from deep green to bronze and gay crimson. Ideal for grouping, particularly around the base of a porch or veranda. Where a dwarf, hardy hedge is wanted, nothing equals this beautiful Barberry. It succeeds in sun or shade and needs very little pruning to keep it in the best shape. The growth is slender and graceful and the branches are prickly with small thorns which makes it very desirable for a defensive hedge. Absolutely hardy in all localities. Plant 12 to 15 inches apart in any good garden soil.

Strong Bushy Plants, 12-15 inches high. $20 \mathrm{c}$ each; 10 for $\$ 1.50$

CALIFORNIA PRIVET-Very vigorous and compact grower of upright habit, widely used for hedges. The foliage is dark green, glossy, broad and firm, clothing the branches very densely. Can be clipped to any form or height wanted. If planted in a single row, set 10 to 12 inches apart; if in a double row, place every 18 inches, so that the plants will be 9 inches apart diagonally in the rows.

Strong 3 to 4 cane plants, 18 inches high.

Each, $15 \mathrm{c} ; 10$ for $\$ 1.00$. Delivery charges prepaid. 25 for $\$ 2.00 ; 100$ for $\$ 7.00$. Delivery charges collect.

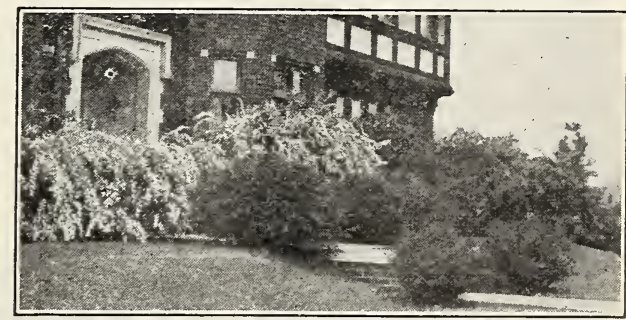

This Shows the Possibilities of Barberry in Groups and Individual Specimens

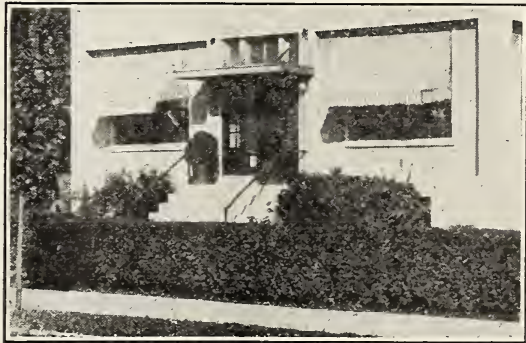

California Privet 


\section{2.}

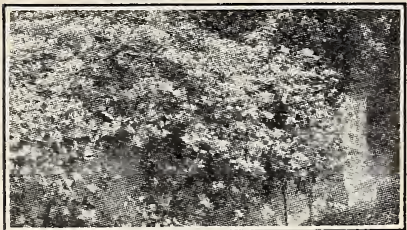

Hall's Japan Honeysuckle

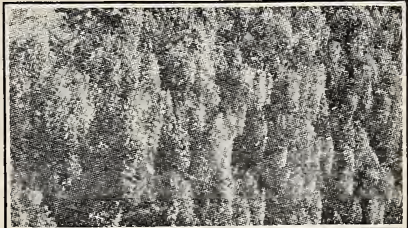

Wisteria in All Its Glory

\section{Hardy Climbing Vines}

\section{Ever Graceful and Charming}

A BEAUTIFUL covering for walls, verandas, or other A harsh outlines, furnishing shade, and lending great charm to barren surfaces. Once established, they practically take care of themselves, proving a delight the whole season through.

AMPELOPSIS VEITCHI (Boston or Japanese Ivy)-A hardy, rapid grower that clings closely to any surface. Foliage, bright, glossy green that turns a brilliant red in Autumn. Fine for city culture. 35c each.

ARISTOLOCHIA SIPHO (Dutchman's Pipe)-A vigorous, tall, twining vine with very large leaves and curious flowers, well adapted for porches and arbors. Perfectly hardy, it thrives in any good garden soil. Flowers are purplish and yellow-green, resembling a pipe in shape. $35 \mathrm{c}$ each.

CLEMATIS PANICULATA-Strong, luxuriant grower, fine green foliage. Produces a mass of starry, white, fragrant clusters of bloom in late summer. $35 \mathrm{c}$ each.

HONEYSUCKLE HALL'S JAPAN-The finest of all Honeysuckles. Rampant in its growth, with dark green leaves densely covering the vines. Flowers white and buff, deliciously fragrant, borne in great profusion all Summer. 25c each.

WISTERIA CHINENSIS (Purple or White)-Especially good for city culture, withstanding the grime and smoke. Very hardy, vigorous grower with a profusion of pea-shaped flowers in dense clusters, 7 to 12 inches long, opening in mid-Spring. We can furnish either the purplish-blue or pure white. 35c each.

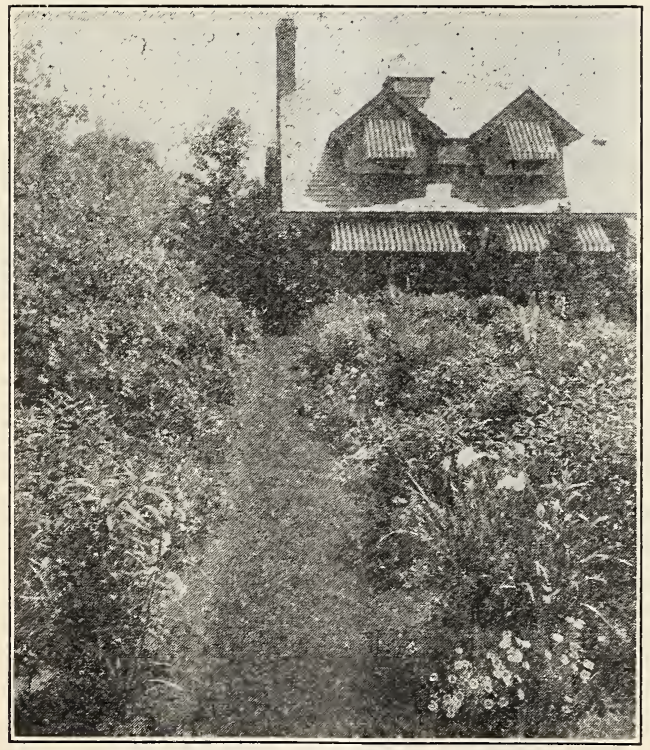

A Gay and Charming Garden

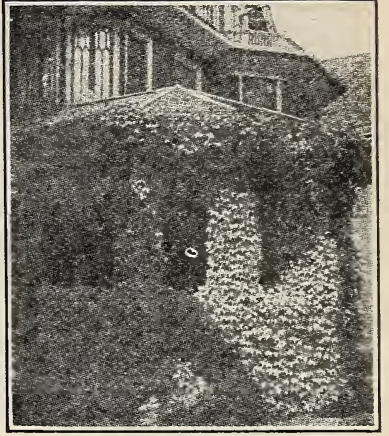

Ampelopsis Veitchi Boston Ivy

\section{Gruss an Teplitz}

(Crimson Hermosa)

\section{Famous Everbloomer for Bedding}

T blooms continuously from early June until stopped by frosts. The flowers are large and full, of the brightest crimson-scarlet; fragrance is delicious and lasting. Growth is rapid, sturdy and erect, with splendid healthy foliage. There is no rose to compare with it for blooming.

Fine One Year Plants, 25c each Strong Two Year Plants, 40c each

\section{Start a Gay and Charming Garden Now}

15 Fine Shrubs and Perennials, $\$ 2.50$

\section{A Complete Planting}

GOR a background, Hardy Flowering Shrubs; for beds and borders, Hardy Perennials that bloom at different times. The result, a garden of continuous and constant delight.

1 Althea Shrub (Rose of Sharon).

1 Forsythia Shrub (Golden Bell).

1 Lonicera Fragrantissima Shrub (Bush Honeysuckle).

2 Spirea Van Houttei Shrubs (Bridal Wreath).

2 Fine, Tall Bearded Iris-assorted colors.

2 Hardy Pinks (Gladys Cranfield).

2 Peonies (Assorted colors).

2 Hardy Chrysanthemums-assorted colors

2 Delphinium Belladonna-stately blue.

Ithaca, N. Y., May 7, 1926.

I wish to say that the Roses I ordered this Spring reached me in fine shape and all are thriving nicely in my flower garden now.

Thanking you for prompt service and extra fine plants.

MRS. CLARA MORENUS. 


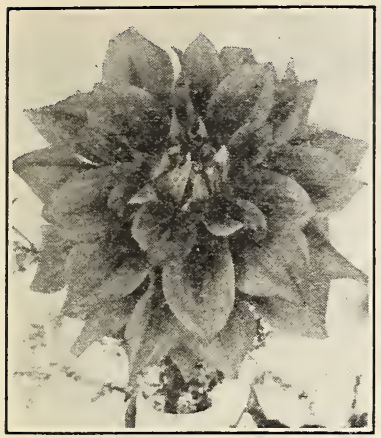

Millionaire

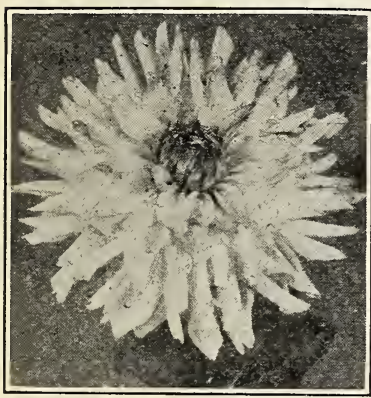

Geo. Walters

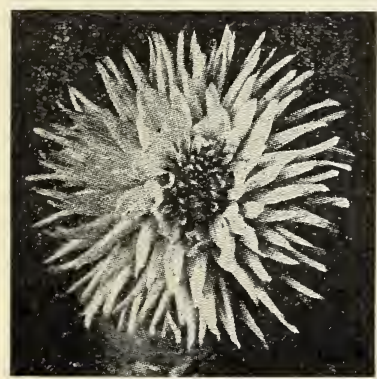

Maude Adams

\section{Beautiful Dahlias}

A $\mathrm{N}$ assortment is offered beA low of the best varieties in various types, covering a wide range of colors to suit every one's taste. Dahlias produce a wealth of color and bloom during the fall, unequalled for garden effect or cut flowers.

They do well in any well-drained soil where the sun shines. Lay the tuber flat on its side, with the eyes pointing upward. Plant about four to six inches deep and about three feet apart.

One Each of the Five Named for $\$ 2.00$

F W FELLOWS (Cactus)-Flowers of unusual size for the long, narrow petaled type. In color it is an intense coral-red with deeper suffusion at the center. Splendid for cutting. 50c each.

MILLIONAIRE (Giant Decorative)Color is a pleasing shade of lavender with a faint pink cast. Wonderful for indoor decorations. The flowers are of gigantic size, frequently measuring 10 to 12 inches across and of unusual depth. 75c each.

MRS. CARL SALBACH (Giant Decorative) - Very desirable, proving entirely satisfactory in all sections. Especially fine for cut flowers and most beautiful in the garden. Flowers are immense in size, of pleasing form and the color is an exquisite shade of lavender. $75 \mathrm{c}$ each.

PIERROT (Cactus)-A unique and striking color; composed of long, narrow tubular petals which are of a deep amber, sometimes showing white tips. Flowers are quite large, of unusual grace, and produced abundantly. 50c each.

PURPLE MANITOU (Decorative)Very remarkable, rich, deep purple. Large flowers on long, stiff stems, making it ideal for cutting. Strong, medium height grower and abundant bloomer. 50c each.

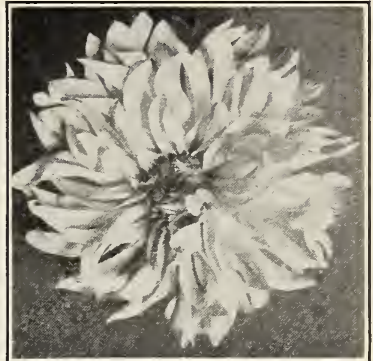

Mina Burgle

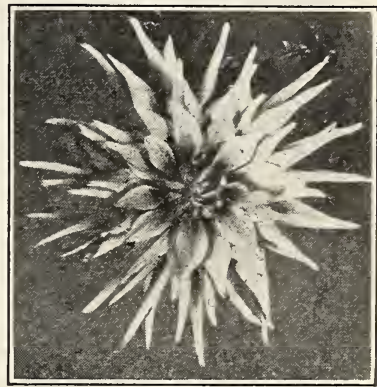

Delice

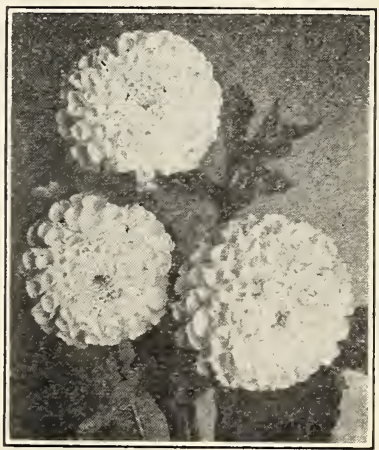

Marguerite Bouchon
One Each of the Six Named for $\$ 1.50$

DELICE (Decorative)-Charming pink, suffused lavender-pink. Fine for cut flowers. 25c each.

MARGUERITE BOUCHON (Cactus)-A beautiful new variety. Flowers are very large and borne on stiff stems well above the foliage. Color is a brilliant rose-pink with delicate white center. 50c each.

MAUDE ADAMS (Show)-Early and very free-blooming variety; dainty, shapely flowers on long stems. Pure white, with a slight lavender suffusion more distinct at the center. 35c each.

MINA BURGLE (Decorative)-Glowing, brilliant, scarlet flowers of gigantic size and remarkable beauty, borne on long, wiry stems, well above the foliage. $35 \mathrm{c}$ each.

OREGON BEAUTY (Decorative)-Very bright vermillion-cardinal, rich and glistening; flowers are immense on long graceful stems. 35 c each.

SOUV. DE. GUSTAV DOAZON (Decorative)Pleasing orange red. Largest Dahlia in existence. 25c each.
One Each of the Eight Named for $\$ 1.50$

A D. LIVONI (Show)-Beautiful, soft pink. Perfectly round, ball-shaped flowers, each petal very tightly quilled. Very free flowering. 25c each.

COUNTESS OF LONSDALE (Cactus)-Deep, salmonred. One of the best ever produced. 35c each.

DREER'S WHITE (Show)-Pure, glistening white, perfectly formed. Very free flowering, strong, bushy grower, ideal for garden and hedges. 35c each.

DUCHESS OF MARLBORO (Cactus)-Rich goldenorange, overlaid silvery-pink. Flowers are splendidly formed with long, narrow, twisted, incurved petals. Excellent for cutting. 35c each.

J. H. JACKSON (Cactus)-Finest, dark, velvety, crimson-maroon. $25 \mathrm{c}$ each.

JACK ROSE (Decorative)-Brilliant crimson-red. 25c each.

LYNDHURST (Decorative) - Brightest orange-scarlet : the best bright red for cutting. An early, free and continuous bloomer on long straight stems. 25c each.

PRINCE OF YELLOWS (Cactus)-A deep, soft, uniform yellow. Perfect in form and color. 25c each. 


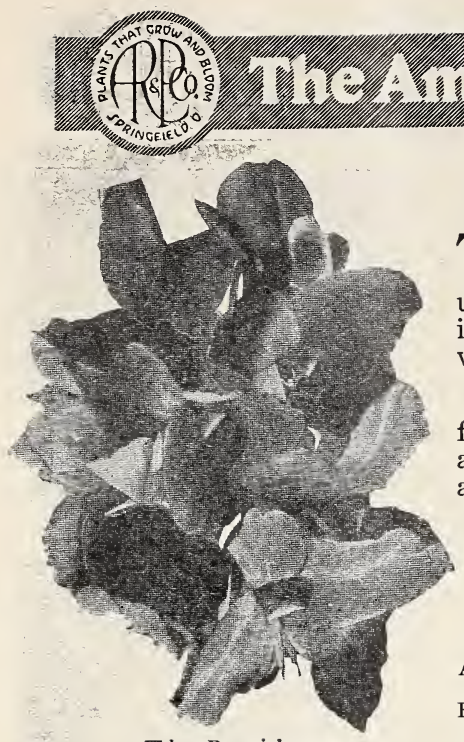

The President

\section{Gay Flowering Cannas}

THEIR brilliancy of color, perfect flower spikes and free blooming qualities, combine to make them the most popular of flowering plants for lawn decoration. Their foliage is of wonderful size, making a full, compact mass that is very effective.

Cannas will grow in any good garden soil and attain their fullest development in any open, sunny location. Plant about three inches deep with the eyes face upward and set about 15 to 18 inches apart.

\section{Ruffled and Orchid Flowering Types in Fine Choice Varieties}

One each of the entire list of 6 for $\$ 1.00$

APRICOT-Very appropriately named, its color being a rich apricot; very distinct and unique. Height, 4 feet. $25 \mathrm{c}$ each; $\$ 2.50$ per doz.

EUREKA-Very fine pure white; the large, substantial, waxy-like flower are freely produced in good, full trusses. Growth is sturdy, foliage fine Height, $4 \frac{1}{2}$ feet. 25c each; $\$ 2.50$ per doz.

GOLDEN GATE-Blooms when opening are almost pure gold, but soon change to orange-crimson and apricot, with deep carmine red at throat. Very striking. Height, $3 \frac{1 / 2}{2}$ feet. 20c each; $\$ 2.00$ per doz.

HUNGARIA-A magnificent soft, rose-pink with large, waxy-like flowers produced in round, full trusses. Height, $3 \frac{1}{2}$ feet. $25 c$ each; $\$ 2.50$ per doz.
MRS. ALFRED CONARD-Large, exquisite salmonpink flowers produced in abundance. Handsome green faliage. Height, 4 feet. $20 c$ each; $\$ 2.00$ per doz.

THE PRESIDENT-The best dark red, retaining its pure, glowing scarlet color indefinitely. Flowers are immense, round and firm, of extra quality, and borne in the greatest profusion. Rich, green foliage. Height, 4 feet. 20c each; $\$ 2.00$ per doz.

\section{Standard Varieties for Every Purpose}

Your choice of any 6 for 75 c. One each of the entire 12 for \$1.25.

AUSTRIA-Golden-yellow, dotted red. Height, 6 feet. 15 c each ; $\$ 1.50$ per doz.

CHAS. HENDERSON-Large and beautiful deep crimson flowers and lovely bright green foliage. Height, 4 feet. $15 \mathrm{c}$ each; $\$ 1.50$ per doz.

CITY OF PORTLAND-A wonderful bright rose-pink Free flowering and vigorous grower. Height $3 \frac{1}{2}$ feet. 20 c each; $\$ 2.00$ per doz.

CRIMSON BEDDER-Dazzling crimson-scarlet. One of the most showy and lasting varieties. Height, $3 \frac{1}{2}$ feet. $15 \mathrm{c}$ each; $\$ 1.50$ per doz.

DAVID HARUM-Foliage dark, glossy-bronze plum flowers orange-scarlet. Height, 4 feet $15 \mathrm{c}$ each $\$ 1.50$ per doz.

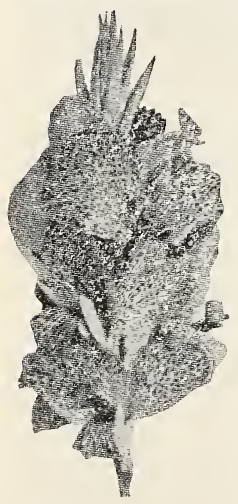

Yellow King

Humbert

WINTZER'S COLOSSAL-The largest-flowered canna yet produced. Flowers are vivid scarlet, eight inches in diameter. Lovely green foliage; free flowering and very attractive. Height, 5 feet. $20 \mathrm{c}$ each ; $\$ 2.00$ per doz.

YELLOW KING HUMBERT (Orchid Flowered)Bright, golden-yellow flowers, dotted red. Height, 4 feet. 15c each; $\$ 1.50$ per doz.

Special Offer-For Round Beds

Plant 18 inches apart each way with one Canna in center

6 FOOT BED-for $\$ 1.00$.

Center-1 Austria-Golden yellow.

First row-2 Austria.

Second row-10 Crimson Bedder-crimson-scarlet.

8 FOOT BED-for $\$ 1.50$

Center-1 Wintzer's Colossal-vivid scarlet.

First row-8 Wintzer's Colossal.

Second row-14 King Humbert-orange-scarlet.

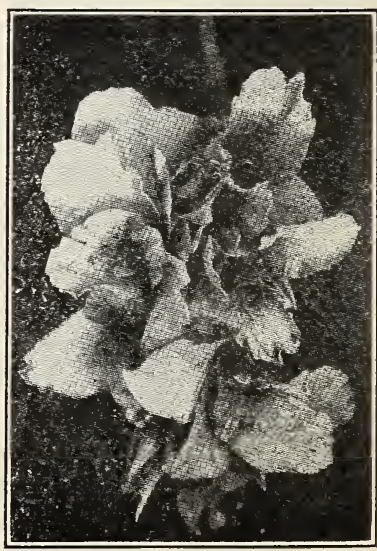

King Humbert 


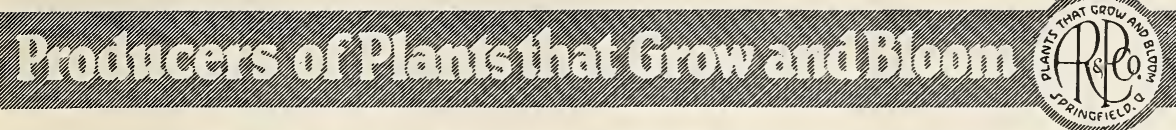

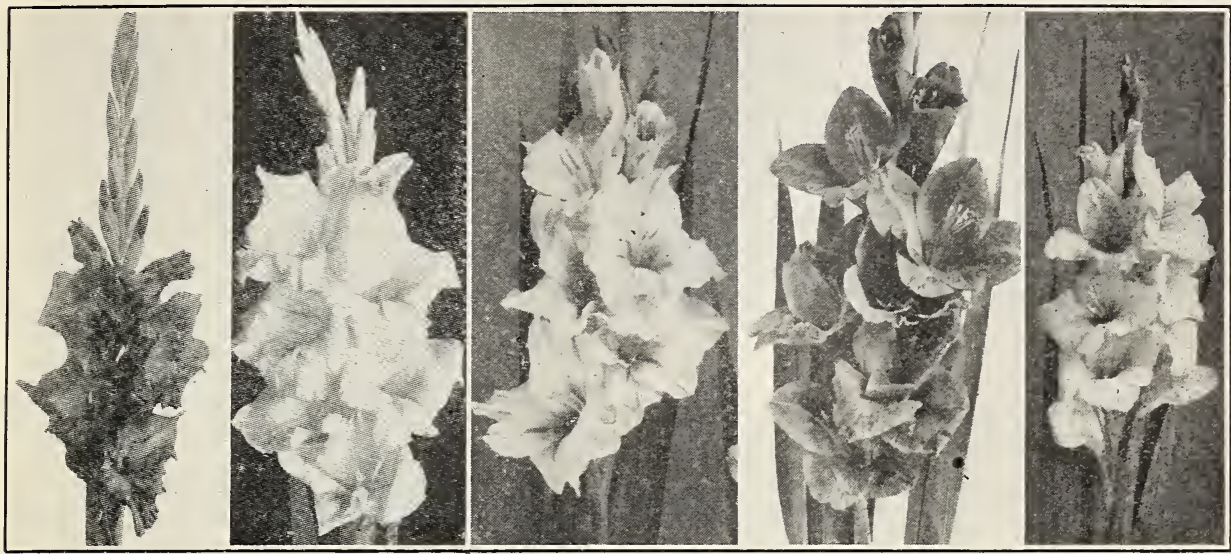

\section{Purple Glory Rose Glory}

\section{Choice New Gladiolus}

A SPECIAL Assortment of the most desirable varieties in the latest productions, unexcelled for cutting and delightful for garden effect.

The entire list of 8 blooming-size bulbs for $\$ 1.00$ BYRON L. SMITH - White, daintily overlaid lavenderpink. Exquisite lily-like flowers of delicate orchidlike coloring. 25c each; $\$ 2.00$ per doz.

CARMEN SYLVA-Pure white lily-like flowers. Largest of its color yet produced, charming in its chaste beauty and purity of color. 25c each; $\$ 2.00$ per doz.

GOLDEN MEASURE-A real yellow, uniform in its perfect richness of golden color. Broad ruffled flowers of marvelous beauty. $30 \mathrm{c}$ each; $\$ 2.50$ per doz.

MONA LISA-Beautiful soft shell pink. Large waxy ruffled flowers. $30 \mathrm{c}$ each; $\$ 2.00$ per dozen.

PURPLE GLORY-Rich, deep, velvety maroon red with black blotches. Beautifully ruffled large flowers. 30c each; $\$ 2.50$ per doz.

REV. EWBANK-Deep, porcelain blue with pronounced red markings in the throat. Adorable color combination, unsurpassed if combined with Golden Measure in bouquets. 25c each; $\$ 2.00$ per doz.

ROSE ASH-Soft old rose, overlaid and blended daphne pink; bases of petals rich yellow, dusted rose. A new pastel shade. $35 \mathrm{c}$ each; $\$ 3.00$ per
doz.

ROSE GLORY - A heavily ruffled rose pink, shading deeper. Marvelous large flowers. 25c each; $\$ 2.00$ per doz.

\section{Gladiolus for House and Garden}

$\mathbf{R}$ EAL favorites are offered in this fine collection of lovely Gladiolus and you can only know their marvelous beauty when you see them blooming in your garden.

\section{Entire list of 12 Fine Bulbs for $\$ 1.00$}

AMERICA - Soft lavender-pink.

$10 \mathrm{c}$ each; $\$ 1.00$ per doz.

AUGUSTA-Pure white with blue anthers. $10 \mathrm{c}$ each; $\$ 1.50$ per doz.

BARON HULOT-A rich royal violet. $15 \mathrm{c}$ each; $\$ 1.50$ per doz.

GLORY-Large ruffled rosy pink. $15 \mathrm{c}$ each; $\$ 1.25$ per doz.

GOLIATH-Claret red with brilliant vevlety sheen.

15c each; $\$ 1.25$ per doz.

HALLEY-Fine soft pink. Earliest bloomer. $10 \mathrm{c}$ each; $\$ 1.00$ per doz.
LE MARECHAL FOCH-Pure delicate rose-pink. $10 \mathrm{c}$ each; $\$ 1.00$ per doz.

MARY FENNELL-Beautiful deep lavender, penciled primrose yellow. $15 \mathrm{c}$ each; $\$ 1.25$ per doz.

MRS. FRANCIS KING-Large bright scarlet. Earliest red. $10 \mathrm{c}$ each; $\$ 1.00$ per doz.

MRS. FRANK PENDLETON-Large orchid-like salmon pink.

10c each; $\$ 1.00$ per doz.

PEACE-Pure white with lilac feathering. $10 \mathrm{c}$ each; $\$ 1.00$ per doz.

SCHWABEN-Clear citron yellow.

10c each; $\$ 1.00$ per doz.

\section{Beautiful Gladiolus}

Mrs. Dr. Norton

To Produce a Wealth of Bloom This Summer SELECTED varieties which produce flowers of exceptional size, embracing a ariety of exquisite tints and shades in endmarkings.

ANNA EBERIUS-Deep carmine rose, overlaid with purple. 25c each; $\$ 2.00$ per doz. delith deeper markings and ITTLE DIAMOND-A gorgeous salmon-pink.

$25 \mathrm{c}$ OUISE-A beautiful clear lavender pink. $15 \mathrm{c}$ each; 25 per doz.

per doz.

20 each ; $\$ 1.50$ and flesh pink. 15c each.

MURIEL-Delicate soft blue with deep purple blotch. 15 c each: $\$ 1.25$ per doz.

WHITE GIANT-Pure glistening white. Formed like oz. 


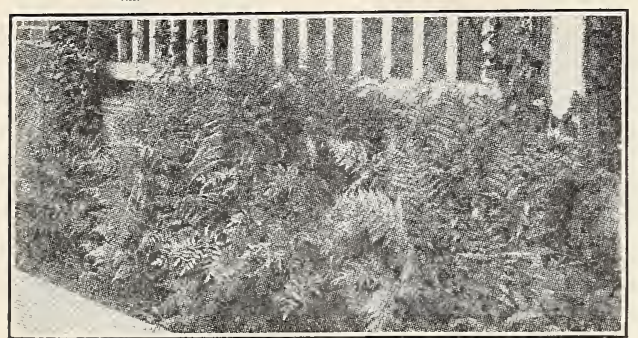

Graceful Hardy Ferns

\section{Hardy Herbaceous Perennials}

$7 \mathrm{HE}$ wonderful, striking and perpetual

charm of the hardy garden flowers have made them indispensable to any garden. Their beauty is ever appealing, ever varying, as each day some new bloom is displaying its beauty. Season after season we find new uses for them with their myriad shapes, colors, time of bloom and their captivating train of enchantment.

CAMPANULA (Canterbury Bells)-They like a good, rich soil and a half shady place. Continuous, free bloomers, fine for edging, rockwork and cutting. Blue, pink, and white. 25c each; 3 for 50c.

DELPHINIUM GOLD MEDAL HYBRIDS-Unquestionably the finest strain of mixed English hybrids. Grows strong and vigorous with large flowers on spikes two feet long and over. All shades of blue, from light to dark. $25 \mathrm{c}$ each; 3 for $60 \mathrm{c}$.

DIANTHUS BARBATUS (Sweet William)-A beautifui bedding variety, which produces great masses of extremely rich and varied-colored flowers. They are of excellent substance, ideal for cutting. $20 \mathrm{c}$ each ; 3 for 50c.

DICENTRA SPECTABILIS (Bleeding Heart)-A beautiful plant, with clustered stems, one to two feet tall. Flowers large and heart-shaped, deep, rosy-red, in nodding, graceful, drooping racemes. Will grow in any good garden soil and is especially partial to shady locations. 50c each; 3 for $\$ 1.25$. and borders. 25c each; 3 for $60 \mathrm{c}$.

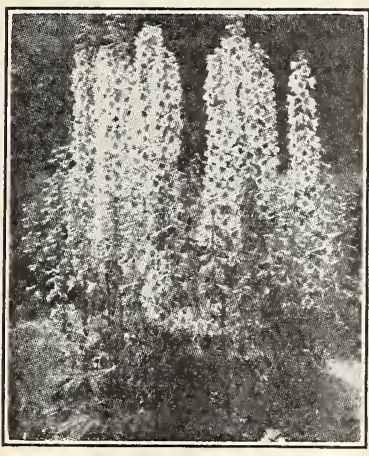

Delphinium

Gold Medals Hybrids

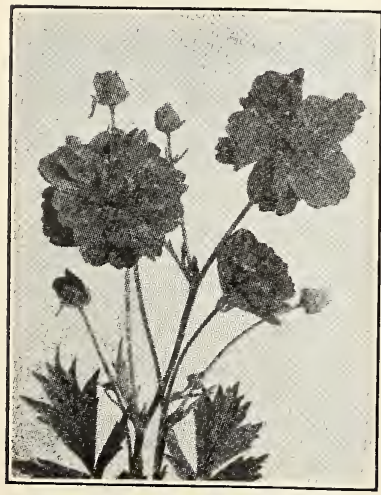

Geum-Mrs. Bradshaw
DIGITALIS (Gloxiniaeflora) Foxglove-Dignified and stately, it is very effective in masses or among shrubbery. Strong flower spikes rise from a rich and luxuriant mass of foliage. We offer these beautiful, fine spotted varieties in white, purple or rose. 20c each; 3 for 5oc.

GAILLARDIA GRANDIFLORA - One of the showiest and most effective hardy plants, growing about 2 feet high and succeeding in any soil in a sunny position, flowering the whole season through. The large flowers are gorgeously colored, center red-brown, petals marked with rings of brilliant crimson, orange and vermilion. Excellent for cutting. $20 \mathrm{c}$ each; 3 for $50 \mathrm{c}$.

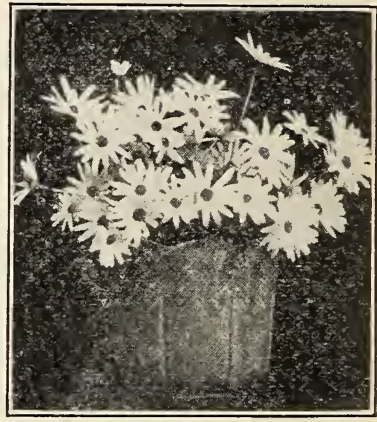

Shasta Daisy

GEUM - MRS. BRADSHAW-Large, double, brilliant scarlet. Pretty border plants, about 15 inches high and producing a mass of showy flowers nearly all Summer. 25c each; 3 for $60 \mathrm{c}$.

GOLDEN GLOW-Indispensable for the hardy border. Strong, robust grower of about five to six feet and produces masses of double, gold e n - yellow cactus-dahlia-like flowers from June until September. They will thrive anywhere, giving a wealth of bloom well suited for cutting. 20c each; 6 for $75 \mathrm{c}$.

GYPSOPHILA (Baby's Breath)-A beautiful well-known plant. It thrives in any sunny position, forming a symmetrical bush 2 to 3 feet in height, producing a mass of minute pure white flowers which gives the plant an exquisite gauzelike appearance. It is wonderful for combining with other cut flowers. $25 \mathrm{c}$ each ; 3 for $60 \mathrm{c}$.

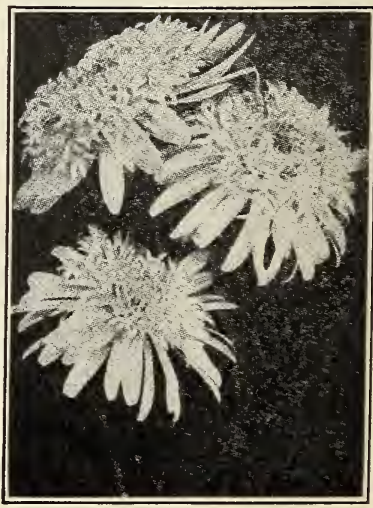

Pyrethrum-Double 


\section{Proulfcers of Platsthat GowandBloom}

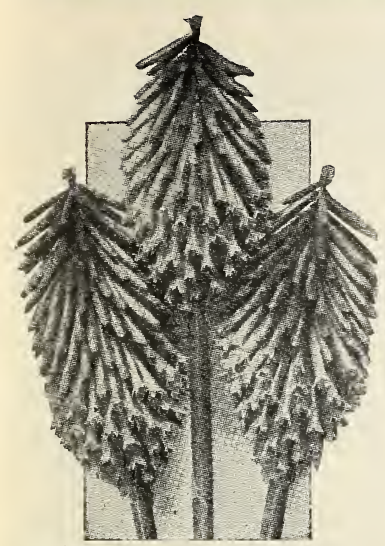

Tritoma (Red Hot Poker)
HARDY FERNS-Two varieties, CINNAMON FERN and MAIDENHAIR -Both very desirable, the Cinnamon fern, tall and broad with a rusty wool when young, thriving in wet soil in sunny or shady places. The Maidenhair must have rich, moist shady location that is well drained. The most graceful and airy of all. $25 \mathrm{c}$ each; 5 for $\$ 1.00$.

HIBISCUS (Mallow Marvel)-A desirable border plant succeeding in sun or shade. Grows three to five feet high, with large foliage and enormous showy flowers of the richest shades of crimson, pink and white, produced the entire summer. $20 \mathrm{c}$ each; 6 for $\$ 1.00$.

HOLLYHOCKS (Double)-Stately, majestic plants, from 6 to 8 feet high, ideal for interspersing with shrubbery or in borders, where their immense spikes of bloom produce bold and showy effects. Their large, Camellia-like flowers form perfect rosettes of the most lovely shades of color. We can supply red, pink,

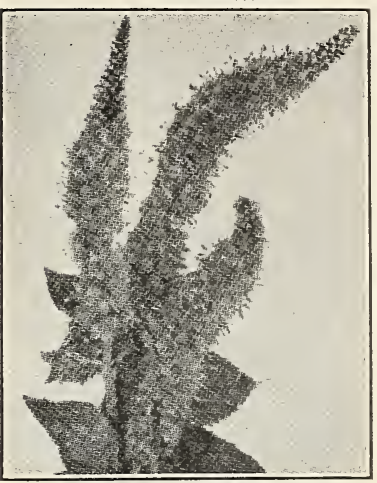

Veronica Spicata

yellow and white shades. 20c each: 3 for $50 \mathrm{c}$

HYPERICUM MOSERIANUM-(See detailed description page 7 ); 50c each; 3 for $\$ 1.00$.

ORIENTAL POPPY-These far surpass poppies of any other kind; for a gorgeous display of rich and beautiful coloring, nothing equals them during their period of flowering in May and June. Immense flowers on wonderful tall stems are produced in this select strain. 20c each; 3 for $50 \mathrm{c}$.

PYRETHRUM HYBRIDUM (Double Flowering)-A great favorite, producing a great mass of fine large

flowers in June and blooming intermittently throughout the Summer and Fall. The fine fern-like foliage is attractive at all times. In mixed colors, crimson, white and pink. 25c each; 3 for 60c.

SCABIOSA CAUCASICA (Blue Bonnet)-One of the most desirable plants producing a profusion of bloom at a season when flowers are scarce. Its charming soft lavender-blue, graceful flowers are produced on stems from 18 to 24 inches high from June to September; splendid for cut flowers. 25c each; 3 for $60 \mathrm{c}$.

SHASTA DAISY (Chrysanthemum Maximum)-One of the most popular garden flowers. It blooms profusely from Spring till Midsummer. Large white daisies with yellow centers carried erect on 2 foot stems. 25c each; 3 for 50 c.

Markle, Ind., February 11, 1926.

I want to tell you what lovely Roses I had last summer. They did not begin blooming until July then there were Roses until frost stopped them and they were perfect. MRS. JAMES J. LIPKEY.

\section{German or Liberty Iris}

VERY effective for massing or borders, or for the foreground of tall growing shrubs; unsurpassed for cut flowers.

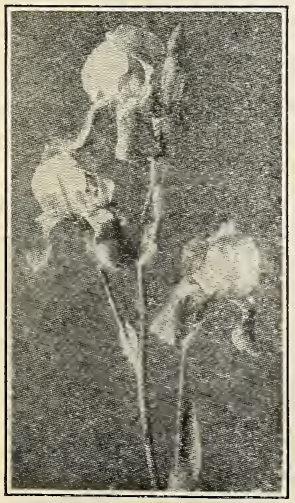

Gagus
"S" means Standards or upper petals. "F" means Falls or lower petals.

Price, 20c each. One each of the 6 named for $\$ 1.00$

DARIUS- "S" yellow. " $F$ " lilac tinted lighter. 30 in.

GAJUS-“S" clear pale yellow. "F" maroon red, heavily veined. $2 \mathrm{ft}$.

LORELEY-“S" light yellow. " $F$ " blue, bordered cream. 32 in.

MANDRALISCAE-Rich $\mathbf{l}$ a v e $\mathrm{n}$ d e r-purple. Tall, handsome, early. 40 in.

MRS. HORACE DARWIN- "S" white. "F" slightly reticulated violet. $2 \mathrm{ft}$.

QUEEN OF MAY-Soft rose-lilac, a decided pink effect. Very popular. 32 in.

If interested in rare and select Iris, write for book on Iris only. All deliveries to be made after blooming time.

\section{Hardy Phlox}

\section{FINE selection of varie-} A ties which produce large trusses of beautiful and brilliant flowers. Effective for massing, borders and cut flowers.

Price $20 \mathrm{c}$ each; one each of the 6 named, $\$ 1.00$.

ETNA-Brilliant salmon-pink.

ISABEY - Exquisite salmonpink.

MISS L I N G A R D - Finest landscape variety. Almost an everbloomer. Pure white with faint lilac eye.

MRS. CHAS. DORR-A beau tiful clear lavender.

MRS. JENKINS - Immense pure white. Early.

RHEINI.ANDER - Salmon pink with claret red eye.

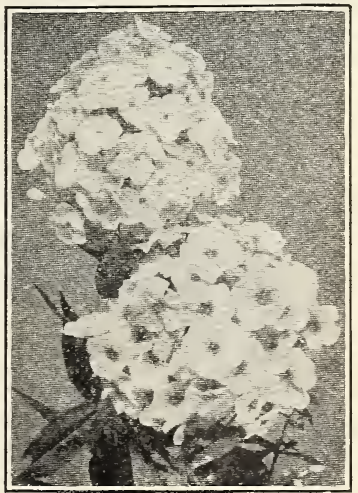

Phlox-Miss Lingard 


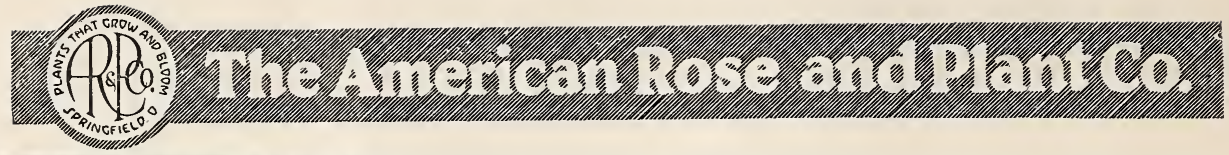

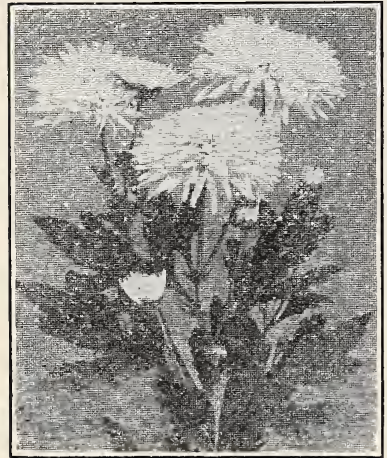

Glory of Seven Oaks

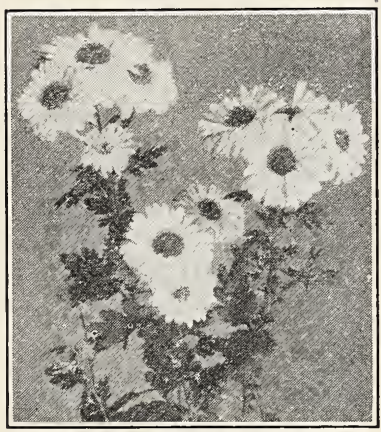

.Quaker Lady

\section{Melrosine CERTAIN DEATH}

The One Universal Contact Insecticide

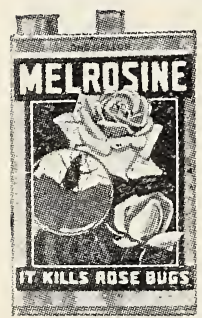

Offering all the convenience and economy of having on hand one preparation to combat various sucking insects. It is effective for most species of Plant Lice, Black Flies, Green Flies, Soft Scale Insects, Rose Leaf Hoppers, Saw Flies, Japanese Beetles, Thrips, Red Spiders, Aster Bugs, Mealy Bugs, etc.

MELROSINE is a concentrated liquid insecticide. The simple directions on every can make it easy to use.

Trial Size

Pint Size

\section{Auto Spray}

For All Light Spraying and Disinfecting

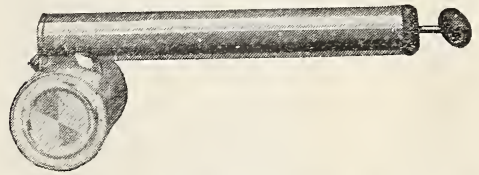

A strong atomizer made of heavy tin. It is singleacting and throws a fine, misty spray. The pump of this Sprayer is fitted with an oil-treated leather cup that lasts.

Pint Size, 75c each. Delivered Parcel Post

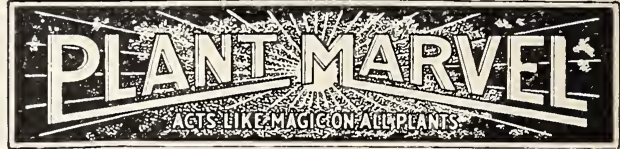

The World's Purest, Richest, QuickestActing, Most Economical Plant Food and Plant Tonic

There's a big difference in plant foods that everyone should know. Plant foods and fertilizers that won't dissolve in water can't be digested by plants. All food must be served to them in "soup" form. The plant foods must be soluble in water. Only then can the porous root hairs take up the needed nourishment.

READ THIS GUARANTEE-Order a package of Plant Marvel today. We assume all risk. If Plant Marvel doesn't show delightful, amazing and better results, go farther, and prove more economical than any other plant food, we will gladly refund your money.

It's so easy to use Plant Marvel now. No Trouble! No Worry! No digging; no damage to the most delicate roots. Merely a small aluminum spoonful of Plant Marvel added to the water, and water the plants as usual. (A handy spoon is now enclosed in every package.)

In 3 Size Packages $25 \mathrm{c}, 60 \mathrm{c}, \$ 1.00$ PLANA EO 2. ED 


\section{Choice Flower Seeds}

UR superior grade of flower seed excels in blooming and growing qualities, producing an amazing profusion of flowers of the most desirable and beautiful types. Fresh, clean seed to give the planter entirely satisfactory returns.

Any packet named below at 10c each. Your Choice of Any Three for 25c, or Any Six for 50c.

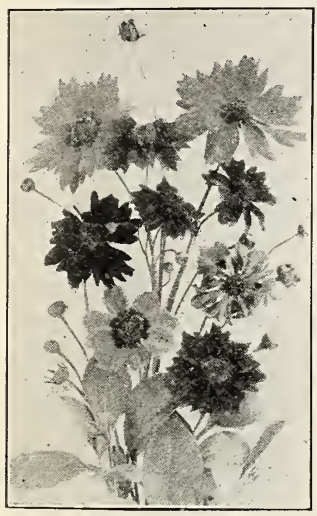

Centaurea

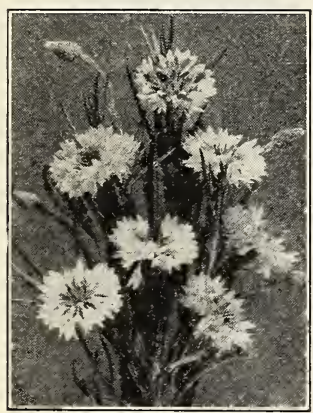

Calliopsis
AGERATUM (Dwarf Blue)-Flowers rich, deep blue.

ASTER (Tall Mixed)-Bright cerise, blue, light blue, shell-pink, delicate rose and pure white flowers.

CARNATION (Marguerite Mixed)-Large, richly spicy fragrant, double flowers.

CELOSIA (Cockscomb)-Tall mixed. Magnificent spikes of feathery-looking flowers.

FORGET-ME-NOT (Myosotis) - Blue clusters. Thrives well in the shade or open border.

HELIOTROPE (Fine Mixed)-Produces small flowers in graceful clusters. Very fragrant.

NASTURTIUM (Fine Dwarf)-A splendid mixture of gay and brilliant colors. Fine for bedding and border effects. One ounce packet.

NASTURTIUM (Climbing or Tall)-Gorgeous colors with lovely markings and tints. One ounce packet.

PANSY (Giant Mixed)-The very best strain in cultivation.

PETUNIA (Fine Mixed)-Single and Double mixed.

PORTULACA (Fine Mixed)-They are in bloom about the first day of July until killed by frost.

SWEET PEAS (Fine Spencer)-Our own special unsurpassable mixture of exclusive soft tints. Flowers are beautifully formed and daintily waved. One-half ounce packet.

SWEET PEAS (Large Flowering)-Bright and pleasing colors in a wonderful mixture. One ounce packet.

SWEET WILLIAM (Double Mixed)-Pure colors and variegated.

SALVIA-Splendens (Scarlet Sage)-Brilliant red, fragrant blossoms.

SHASTA DAISY (Alaska)-Large, glistening white flowers, borne from early Summer to late Fall.

VERBENA (Mammoth Mixed)-A fine bedder, brilliant in color, excellent habit of growth and of long duration of bloom.

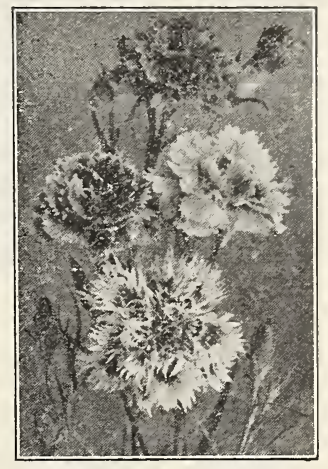

Dianthus

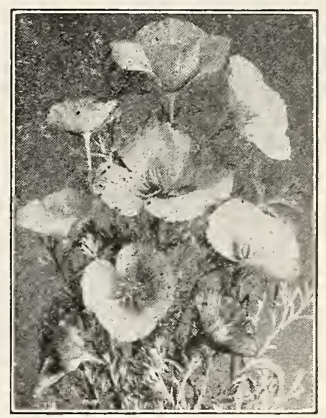

Escholtzia

Any Packet named below at 5c each; Your Choice of Any Six for 25c or Any Twelve for 50c. ANTIRRHINUM (Snap Dragon)-The dense, wellformed trusses contrast beautifully with the deep green foliage. Splendid, large, double, Camellialike flowers.

BALSAM (Camellia Flowered)-Double Mixed. Border plant. Large, double flowers, varying in colors of rich orange and yellow.

CALENDULA (Double Mixed)-Very showy golden yellow.

CALLIOPSIS (Tall Mixed)-Flowers of brilliant, golden yellow, showing a vivid reddish splotch in the center.

CAMPANULA (Canterbury Bells)-Dainty, bell-shaped flowers.

CANDYTUFT (Fine Mixed)-Large spikes of purest white flowers. Growth, low and compact.

CENTAUREA (Bachelor's Button)-Large, thistle-like, beautifully colored flowers of white, mauve and purple.

COSMOS (Giant Flowering)-Feathery foliage and large, showy blossoms. Colors, gorgeous reds, pinks and whites.

DELPHINIUM (Larkspur)-Their long, showy spikes of clear turquoise blue flowers are not equaled in delicacy and beauty by any other.

DIANTHUS (Chinese Double Pinks)-This mixture contains the largest and most fragrant sorts of varied shades and markings.

ESCHOLTZIA (California Poppy)-Beautiful velvety, cup-shaped flowers of rich and varied hues. Fine mixed.

FOXGI.OVE (Digitalis)-Lovely bell-shaped flowers produced on long spikes. Fine Mixed.

GAILLARDIA (Single and Double)-Color combinations varying between gold and maroon.

MARIGOLD (African Tall Mixed-Enormous, globular flowers; primrose to yellow and deep orange.

MIGNONETTE (Large Flowering)-Pyramida!-shaped spikes of exceedingly fragrant blossoms.

MORNING GLORY (Fine Mixed)-Very useful for covering lattice-work, verandas, etc.

POPPY (Fine Double Mixed)-Gloriously brilliant.

SWEET ALYSSUM (Snow Carpet)-Pure white flowers of sweet honey fragrance.

ZINNIA (Elegant Tall Mixed)-The improved, compact, large flowering Zinnia. 


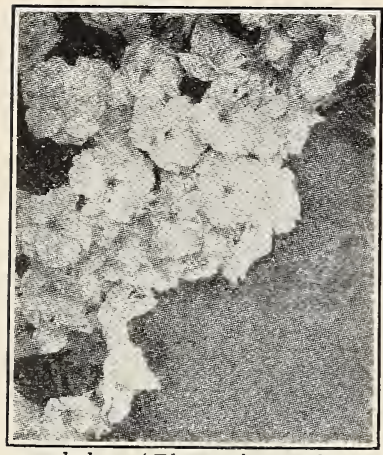

A mygdalus (Flowering Almond)

\section{Amygdalus (Flowering Almond) \\ A Showy Flowering Hardy Shrub}

A BEAUTIFUL, dwarf shrub with erect, slender branches, $\mathrm{A}_{\text {which are literally covered in early May with exquisite, }}$ double pink flowers, delightfully fragrant. This mass of bloom comes before the leaves appear, but the growth is so shapely and foliage so ornamental that it is a very desirable variety. It will thrive in any good garden soil and while it may be massed with other shrubs, the fullest extent of its showy beauty can be realized best when it is set alone and grown as a single specimen.

Fine large field grown plants, 75 c each; 3 for $\$ 2.00$.

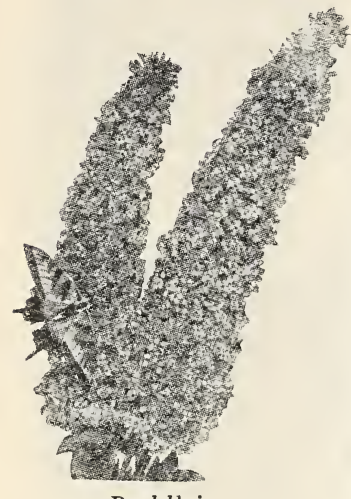

Buddleia

\section{Buddleia (Butterfly Bush)} Summer Lilac

$\mathrm{O}$ $\mathrm{NE}$ of the most desirable summer flowering shrubs, blooming uninterruptedly from early June until late frost. The long cylindrical panicles of bloom (from twelve to fifteen inches) contain hundreds of miniature flowers of beautiful, deep purple-lilac color, and have a pleasing fragrance which greatly attracts scores of butterflies, hence its name "Butterfly Bush." It succeeds in any good garden soil, flowering freely the first season planted, and the long, gray-green leaves add greatly to its beauty. Makes a delightful specimen
Beauty and Fragrance
in this Special Garden
Collection
These New and Beautiful Roses
Delivered to You.
Six Fine One Year Plants for
\$1.00.
Six Strong Two Year Plants for
\$2.25.
Columbia-Clear rose-pink.
General MacArthur-Dazzling red
La France-Soft, silvery pink.
Sunburst-Rich orange-copper
White Killarney-Pure white
Ophelia-Salmon-pink and is very attractive in groups. After the first frost, the tops should be cut off nearly to the ground and a good mulch given the plant. New and sturdy growth is thus assured for the following season. Fine, Strong Plants-Price, 50c each; 3 for $\$ 1.00$.

\section{INSTRUCTIONS FOR ORDERING}

When ordering, please use the Order Sheet and Envelope provided for that purpose.

\section{Delivery Charges Paid}

All stock we offer is shipped by parcel post, postage paid by us, so there are no charges to be collected when shipment is received. The prices asked cover these delivery charges.

\section{Terms}

Our terms are cash with order, and your remittance should be made in Cash, Postoffice Money Order or Draft. Please do not ask us to make C. O. D. shipments.

\section{Packing}

Special care is exercised in packing, thus avoiding all chance for damage on the way, no matter how far the plants have to go. Our perfect packing insures safe arrival, and we guarantee all stock to reach our customers in good, healthy condition. With each package we send complete directions for planting, care and culture.

\section{Time of Shipment}

Unless you instruct us otherwise when sending your order, immediate shipment will be made. If you want us to hold plants until proper time to set out in your locality, kindly state this when ordering.

\section{Guarantee}

We guarantee that all plants we send out will be in good, healthy growing condition when they leave our packing room and to reach destination in the same condition. Complaint should be made immediately upon receipt of goods, if they arrive damaged in any way.

We cannot guarantee plants to grow for you, as this is governed by planting, care and attention given them, but each and every one we send you will respond eagerly if set out in good garden soil and furnished with water and sunlight. 


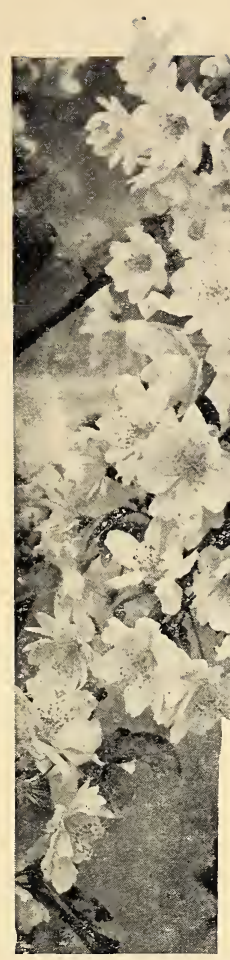

MALUS

Scheideckeri

Individual

Flowers

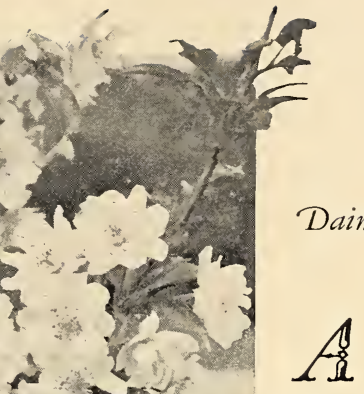

Dainty and Fragrant-Showiest and Most Gorgeous Spring Flowering Shrub

lowed by gay and ornamental fruit. The great profusion of the large double fragrant flowers, almost obscuring the branches, give the effect of clothing the shrub in shimmering transparent silk gauze. They present striking effects when planted along a drive or used for a hedge and prove equally valuable as single specimens on the lawn or massed in open or woodland plantings.

They will grow in any soil, but of course, one is rewarded by more remarkable and quicker results if good garden soil and some cultivation is afforded them.

We offer you the two most desirable sorts:-

MALUS NIEDZWETZKYANA is a very early bloomer, best noted for the wonderful red color of flowers, branches, leaves and fruit.

MALUS SCHEIDECKERI is also a very early bloomer, producing huge masses of flowers, bright rose colored (even on very young plants) in an upright bottle-brush formation on the stems, followed with an abundance of ornamental fruit.

\section{Special Offer}

Large 2 year field grown plants - - $\$ 1.00$ each Plants that will give you immediate effect.

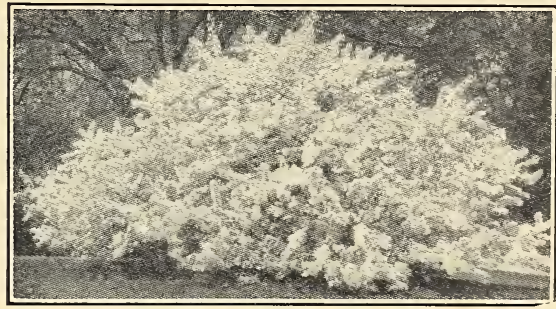

Malus Scheideckeri Specimen Plant

\section{Fine Shrubs for $\$ 3.00$ A Permanent and Complete Planting Delivered to You}

They require no special care and attention and once they are planted, they will thrive for years to come, increasing in beauty each season.

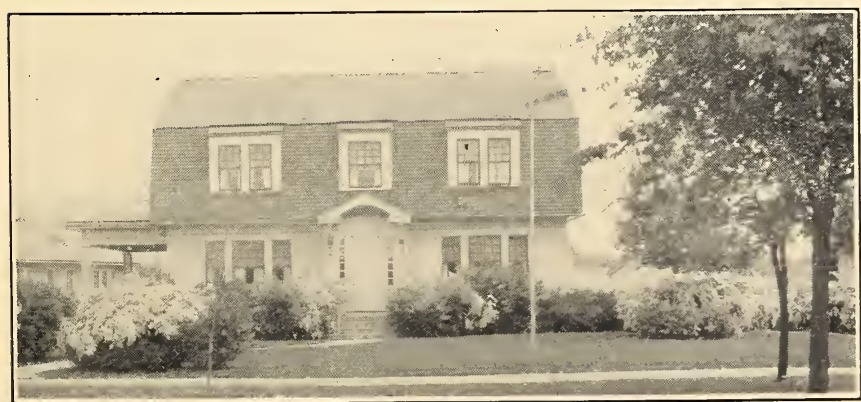

An Attractive Foundation Planting
3 Barberry Thunbergi (Japanese).

1 Deutzia, large flowering white.

1 Forsythia (Golden Bell).

1 Hydrangea Ar borescens Grandiflora A l b a ( $\mathrm{Hills}$ of Snow).

1 Hydrangea Paniculata Grandiflora.

3 Spirea Anthony Waterer (red everblooming ).

3 Spirea Van Houttei (Bridal Wreath).

2 Spirea Thunbergi (Snow Garland). 


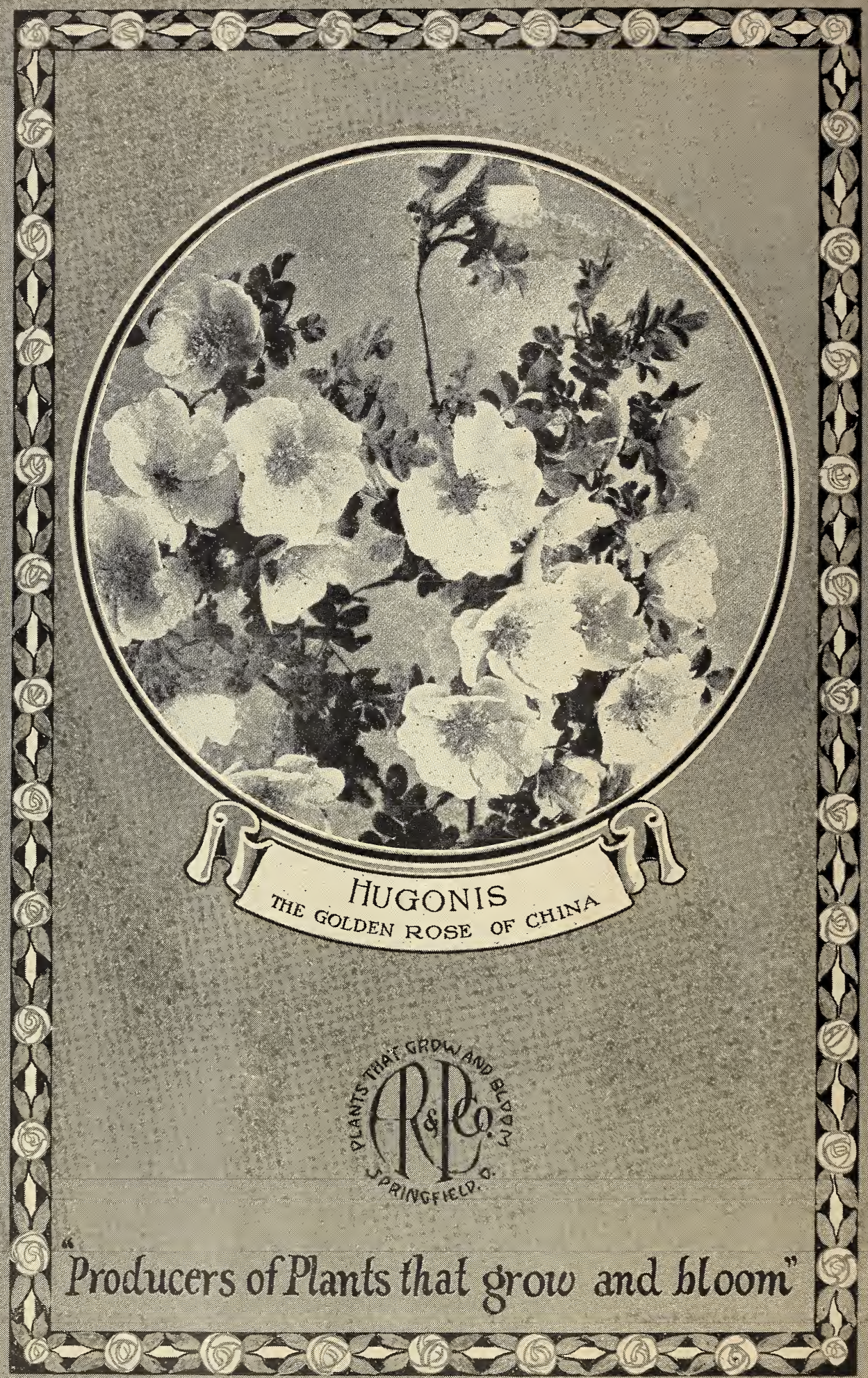

